\title{
Sensitivity of freshwater dynamics to ocean model resolution and river discharge forcing in the Hudson Bay Complex
}

\author{
Natasha A. Ridenour ${ }^{\mathrm{a}, *}$, Xianmin $\mathrm{Hu}^{\mathrm{a}, 1}$, Shabnam Jafarikhasragh ${ }^{\mathrm{b}}$, Jack C. Landy ${ }^{\mathrm{c}}$, \\ Jennifer V. Lukovich ${ }^{\mathrm{b}}$, Tricia A. Stadnyk ${ }^{\mathrm{d}}$, Kevin Sydor ${ }^{\mathrm{e}}$, Paul G. Myers ${ }^{\mathrm{a}}$, David G. Barber ${ }^{\mathrm{b}}$ \\ ${ }^{a}$ Department of Earth and Atmospheric Sciences, University of Alberta, Edmonton, Alberta, Canado \\ ${ }^{\mathrm{b}}$ Center for Earth Observation Science, University of Manitoba, Winnipeg, Manitoba, Canada \\ ${ }^{\mathrm{c}}$ Bristol Glaciology Centre, School of Geographical Sciences, University of Bristol, Bristol, United Kingdom \\ ${ }^{\mathrm{d}}$ Department of Civil Engineering (Water Resources), University of Manitoba, Winnipeg, Manitoba, Canada \\ ${ }^{\mathrm{e}}$ Manitoba Hydro, Winnipeg, Manitoba, Canada
}

A R T I C L E I N F O

\section{Keywords:}

Hudson Bay Complex

River runoff

Freshwater

Dynamics

Ocean modelling

\begin{abstract}
A B S T R A C T
Hydroelectric development and regulation have modified the temporal and spatial distribution of runoff entering the Hudson Bay Complex (HBC). To understand the impacts and future of regulation in this region, the numerical ocean model, NEMO, run with the Arctic and Northern Hemispheric Atlantic (ANHA) configuration, is used to model present day freshwater dynamics associated with river runoff and sea ice melt. The present work establishes the freshwater budget in each subregion of the HBC, in addition to evaluating the sensitivity to model resolution and estimates of river discharge forcing. It is shown that the annually averaged HBC freshwater budget is mainly a balance between river discharge and freshwater advected out of the region, while surface fluxes (ice melt and growth, and precipitation and evaporation) are the dominant term on seasonal time scales. Runoff forcing is found to impact the long term mean volume and freshwater fluxes out of the HBC, while increased resolution has minimal effect on these fluxes, with the exception of the Southampton-Baffin Island gate. Quantitative estimates of turbulent, mean, and Ekman components of freshwater exchange between the interior and boundary regions of Hudson Bay are also presented. We use offline Lagrangian passive tracers to estimate the HBC runoff residence time, which is as long as 32 years.
\end{abstract}

\section{Introduction}

Anthropogenic changes such as global warming, which is causing an intensification of the hydrological cycle in the Arctic region (Zhang et al., 2012; Déry et al., 2009), as well as hydroelectric development, are changing the river discharge in northern Canada (Déry et al., 2011, 2016, 2018; MacDonald et al., 2018). One such region undergoing these changes is the Hudson Bay Complex (HBC), which includes Hudson Bay, James Bay, and neighbouring basins, Foxe Basin, and Hudson Strait and Ungava Bay, shown in Fig. 1. The HBC receives about 900 $\mathrm{km}^{3} /$ year of river runoff, equivalent to roughly three times the Mackenzie River (Shiklomanov and Shiklomanov, 2003; Holmes et al., 2012), causing this region to be quite fresh compared to the Arctic Ocean. The main pathway of heat, mass, and freshwater exchange between the HBC, the Arctic, and the North Atlantic is via Hudson Strait. This river water flows out of Hudson Strait and along the coast of
Labrador in the Labrador Sea, where deep convection occurs (Aagaard and Carmack, 1989; Straneo, 2006; Lazier et al., 2002; Lozier et al., 2019). The role of the fresh Hudson Strait outflow in these processes, however, is still largely unknown. This study aims to provide multi-year estimates of the HBC freshwater budget, so as to understand the role of model resolution and river discharge on freshwater fluxes within the HBC as well as to the North Atlantic.

Isolated from large scale ocean circulation, the main sources of freshwater to the HBC are river discharge and sea ice melt (Prinsenberg, 1988). On time scales less than a year, sea ice melt/growth has a much larger role in the freshwater budget compared to river discharge (Prinsenberg, 1988). Freshwater sourced from river discharge is found mainly along the coast, while freshwater from sea ice melt is distributed more equally around the bay (Granskog et al., 2007, 2011).

Spatially, the distribution of freshwater within Hudson Bay can be divided into two regions, the outer boundary region and the interior

\footnotetext{
* Corresponding author.

E-mail address: ridenour@ualberta.ca (N.A. Ridenour).

${ }^{1}$ Now at Bedford Institute of Oceanography, Dartmouth, Nova Scotia, Canada.
} 


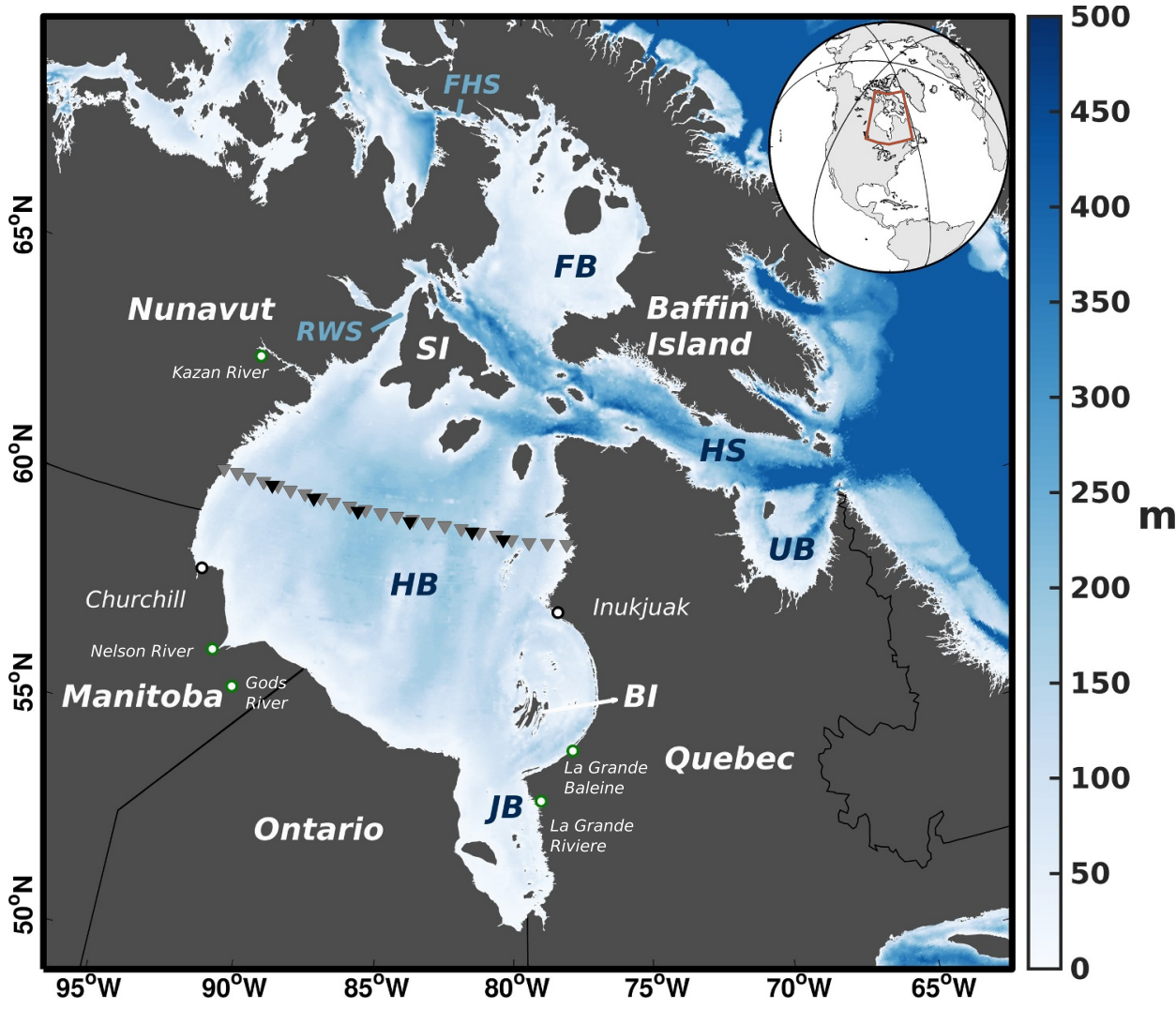

Fig. 1. Bathymetry of the Hudson Bay Complex (HBC). Abbreviations for geographic locations and features are as follows: FB = Foxe Basin, HS = Hudson Strait, UB = Ungava Bay, $\mathrm{HB}=$ Hudson $\quad$ Bay, $\quad \mathrm{JB}=$ James Bay, SI $=$ Southampton Island, FHS $=$ Fury and Hecla Strait, RWS = Roes Welcome Sound, and $\mathrm{BI}=$ Belcher Islands. The towns of Inukjuak and Churchill are shown by the black rimmed circles, while river outlets are shown by green rimmed circles. Grey triangles show the model transect, and black triangles show observations, used for Fig. 5. (For interpretation of the references to colour in this figure legend, the reader is referred to the web version of this article.) region. The exchange of freshwater between the interior and boundary regions is mainly driven by Ekman transport (St-Laurent et al., 2011). In summer, the freshwater is imported into the interior, and is released during the fall (St-Laurent et al., 2012).

In the context of climate change, the length of the ice free season in the HBC is increasing, with both earlier break up in spring (Gough et al., 2004a; Gagnon and Gough, 2005; Castro de la Guardia et al., 2017; Hochheim and Barber, 2014; Kowal et al., 2017) and later freeze up in the fall (Gagnon and Gough, 2005; Castro de la Guardia et al., 2017; Hochheim and Barber, 2014; Kowal et al., 2017). These changes have been found to be related to the region's air temperature (Hochheim and Barber, 2014; McGovern and Gough, 2015). Hochheim and Barber (2010) found, for every $1^{\circ} \mathrm{C}$ increase in the region's mean air temperature, it can result in a decrease of $105,000-117,000 \mathrm{~km}^{2}$ in late November sea ice extent with concentrations $>80 \%$. Sea ice thickness, on the other hand, is weakly related to air temperatures (Gough et al., 2004b). Ice thickness derived from satellite altimetry (Landy et al., 2017) shows a significantly asymmetrical spatial pattern across Hudson Bay in spring due to the strong cyclonic ice drift in winter. Their study also estimated $742 \pm 10 \mathrm{~km}^{3}$ of freshwater is stored in sea ice within the bay in April.

Anthropocentric influences have also impacted the HBC river discharge. Discharge entering the HBC has increased (Déry et al., 2016), which is associated with the intensified hydrological cycle in the context of Arctic warming (Déry et al., 2009, 2011, 2016; Zhang et al., 2012; Rawlins et al., 2010). Seasonally, hydroelectric development has increased winter HBC streamflow (Déry et al., 2011). Increasing air temperature also leads to earlier spring peak runoff (Déry et al., 2005; Gagnon and Gough, 2002), however, this varies regionally (Gagnon and Gough, 2002). Under the $1.5^{\circ}$ and $2^{\circ} \mathrm{C}$ future warming scenarios, MacDonald et al. (2018) found discharge increased in all seasons, except summer, with the largest increases occurring in spring.

In light of these current trends, it is still unclear as to the impact that these changes will have on the freshwater dynamics in this region. The annual net freshwater flux of river discharge is large, thus, changes in river runoff, by seasonal and spatial redistribution, or long term trends, lead to changes in seawater density and stability. A high runoff year and regulated discharge have been shown to lead to a decrease in salinity, along with a general increase in sea ice thickness (Saucier and Dionne, 1998).

To date, there have been no multi-year evaluations of the freshwater budget in this region. Other questions remain regarding the freshwater budget, for instance, how important are small scale processes in HBC dynamics? Does the freshwater budget change with changes in river runoff? To determine the sensitivity of the HBC to runoff forcing as well as model resolution, we use a general circulation ocean model coupled with a sea ice model to evaluate the freshwater budgets, pathways, and boundary-interior exchange processes of each simulation. The following section contains a description of the model, as well as the various datasets used in the numerical experiments. In Section 3, an evaluation of the model and the freshwater budgets for each subregion in the HBC, as well as boundary-interior freshwater exchanges and riverine water residence time, are shown. Our analysis of the residence time is in Section 3.4, preceding the summary and conclusions. This work is part of the BaySys project, a bay-wide initiative to investigate effects of hydroelectric regulation and climate change on various aspects of the Hudson Bay environment, such as the biogeochemical, biological, and physical components of the system.

\section{Methods and data}

\subsection{Numerical model}

We use a general circulation ocean model, based on the Nucleus for European Modelling of the Ocean version 3.4 (NEMO; Madec and the NEMO team, 2008), which is coupled to the sea ice model, Louvain-laneuve Ice Model version 2 (LIM2) with elastic-viscous-plastic (EVP) rheology (Hunke and Dukowicz, 1997), and includes both 

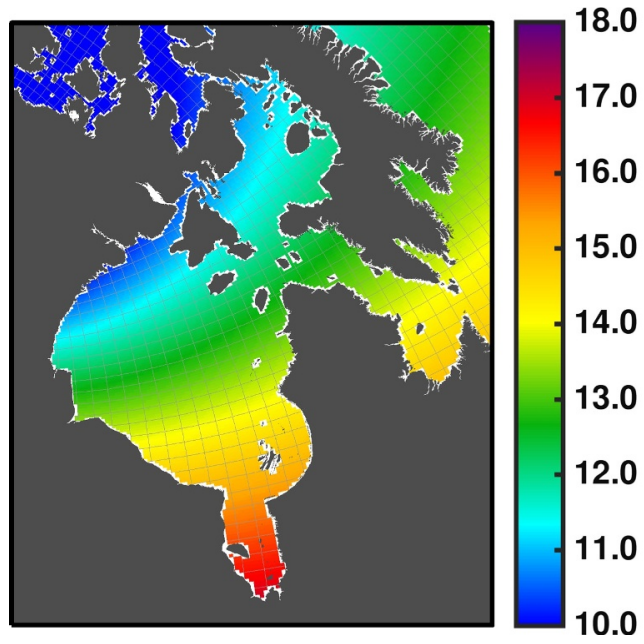

(a)

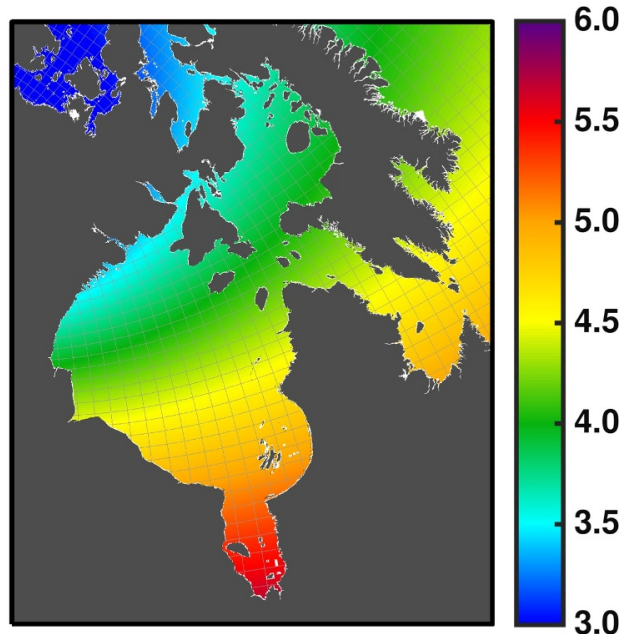

(b)

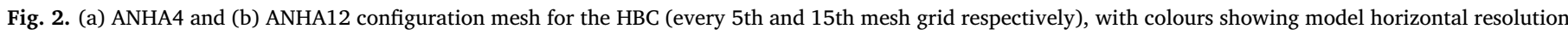
in kilometers.

thermodynamic and dynamic processes (Fichefet and Maqueda, 1997), for our simulations. We use the Arctic and Northern Hemisphere Atlantic (ANHA) configuration, which has two open boundaries, one at Bering Strait and the other at $20^{\circ} \mathrm{S}$ in the Atlantic Ocean. Two horizontal resolutions are used in our study, $1 / 4^{\circ}$ (ANHA4) and $1 / 12^{\circ}$ (ANHA12) (Holdsworth and Myers, 2015; Dukhovskoy et al., 2016; Gillard et al., 2016; Müller et al., 2017; Hu et al., 2018), meaning the resolution within the HBC is $10-17 \mathrm{~km}$ for ANHA4 (Fig. 2a), and $3.5-5.5 \mathrm{~km}$ for ANHA12 (Fig. 2b). Vertically, there are 50 geopotential levels that have the highest resolution at the surface and decrease in resolution with increasing depth. For the vertical mixing scheme, we use a turbulent kinetic energy (TKE) turbulence closure scheme (Bougeault and Lacarrere, 1989; Gaspar et al., 1990; Blanke and Delecluse, 1993; Madec et al., 1998). Our simulations do not use temperature or salinity restoring so as to not damp the freshwater signals. Tides are also not included in these simulations as we will focus on large scale processes. We use 5-day averaged output from the model for our analysis, however, the time step for each resolution is $1080 \mathrm{~s}$ and $180 \mathrm{~s}$ for ANHA4 and ANHA12 respectively.

Our simulations are initialized with 2D (sea surface height and sea ice) and 3D (temperature, salinity, and horizontal velocities) fields from GLobal Ocean ReanalYsis and Simulations (GLORYS2v3) produced by Mercator Ocean (Masina et al., 2017). Boundary conditions, such as salinity, temperature, and ocean velocities are also provided by the GLORYS2v3 dataset. We use atmospheric forcing from the Canadian Meteorological Centre's (CMC) global deterministic prediction system (GDPS) reforecasts (CGRF) described in Smith et al. (2014), along with CORE bulk formulae (Large and Yeager, 2004). This dataset provides $2 \mathrm{~m}$ air temperature and specific humidity, $10 \mathrm{~m}$ wind, downwelling shortwave and longwave radiation flux, and total precipitation to the surface at high temporal(hourly) and spatial $(33 \mathrm{~km})$ resolution. We integrate our simulations from January 2002 to December 2016. Monthly interannual runoff (described more in Section 2.2), as well as Greenland melt water provided by Bamber et al. (2012) is also carefully remapped onto the model grid to have more realistic freshwater input from land to ocean. The temperature of discharge when entering the ocean is given the same temperature as the surrounding seawater, a typical approach of ocean general circulation models when no reliable discharge temperature is available.

\subsection{Runoff datasets}

To test the model sensitivity to runoff forcing, we use three river discharge datasets: corrected Dai and Trenberth (referred to as DT; Dai and Trenberth, 2002; Dai et al., 2009), and two products from HYdrological Predictions for the Environment (HYPE; Lindström et al., 2010; Gelfan et al., 2017; Andersson et al., 2013) provided by BaySys Team 2. In this case, the HYPE model simulates streamflow for 398 streams and rivers draining into the HBC. One of the HYPE datasets used here is uncalibrated HYPE simulated streamflow that has been integrated with observed streamflow. Where observations are available, HYPE discharge is replaced with gap-filled observations from Déry et al. (2016). We also note that observed discharge for La Grande Riviere (second largest river by volume) was not used, and the uncalibrated HYPE model underestimates La Grande Riviere discharge. Thus, for the purposes of this study, this integrated, uncalibrated version of HYPE discharge will be referred to as HIUC. The second HYPE streamflow product used is from the calibrated version of HYPE, which we will refer to as HCAL. This runoff dataset has not been integrated with observations, but includes the improvements to the model, such as better representation of La Grande Riviere discharge and Nelson River regulated discharge. HCAL and HIUC discharge extends to 2013 and 2010 respectively. We use the final year as forcing for the remaining years up to 2016. This is also the case for DT, which ends in December 2007. For consistency, throughout the study we compare the two HYPE datasets to DT, as DT is the standard river discharge dataset used for forcing ocean models. DT interannual runoff is used for the entire configuration for the control (CTRL) and high resolution (HIRES) experiments. The HYPE datasets are used in the HBC, with DT runoff used elsewhere in the third and fourth experiments (HIUC and HCAL). All runoff datasets are prescribed as monthly averages.

The seasonal cycles of the three runoff datasets used in the HBC in this study are shown in Fig. 3. The DT discharge is larger than the HIUC discharge in most months, due to the gap filling strategy used for the dataset, most notably during the spring freshet, with differences peaking at $1.53 \mathrm{~km}^{3} /$ day in May. The difference between DT and HCAL also peaks in May at $1.07 \mathrm{~km}^{3} /$ day. All datasets show a secondary runoff peak in the fall, with the DT dataset having a more level peak spanning September and October. Throughout the year, DT discharge averages at $2.99 \mathrm{~km}^{3} /$ day (dark blue dashed line, Fig. 3), HIUC averages at $2.45 \mathrm{~km}^{3} /$ day (light blue dashed line), HCAL has an annual average discharge of $2.54 \mathrm{~km}^{3} /$ day (green dashed line, Fig. 3). This 


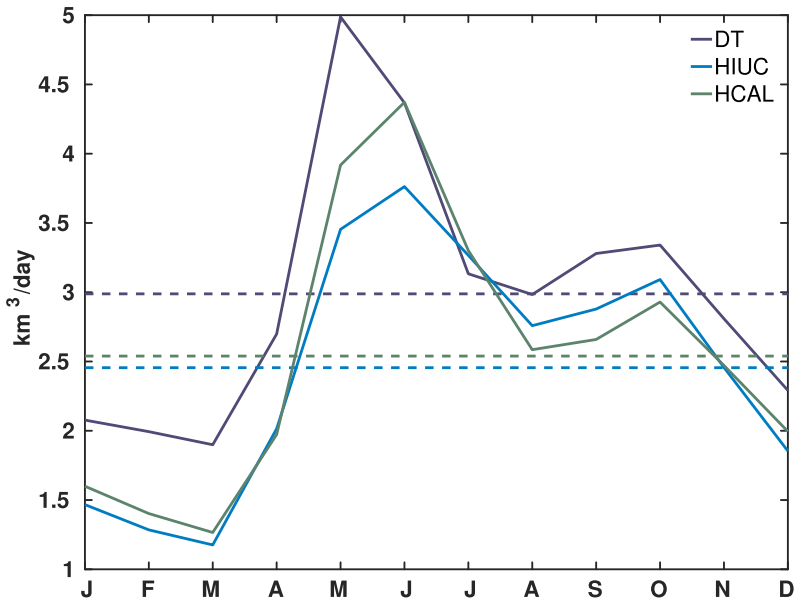

Fig. 3. Seasonal cycle of the three runoff datasets used, averaged from 2004 to 2007, the common period of all datasets used, for the HBC. Dai and Trenberth discharge is represented by dark blue lines, where the solid line is the seasonal cycle and the dashed line is the mean discharge. Similarly, seasonal and mean HIUC discharge is shown by the solid and dashed light blue lines respectively, and HCAL by the green solid and dashed lines. (For interpretation of the references to colour in this figure legend, the reader is referred to the web version of this article.)

difference leads to nearly $200 \mathrm{~km}^{3} / \mathrm{yr}$ more runoff in the DT dataset compared to HIUC, and over $150 \mathrm{~km}^{3} / \mathrm{yr}$ compared to HCAL.

\subsection{Residence time estimation}

To estimate the residence time of river runoff in the HBC, we use an offline Lagrangian tool called Ariane (Blanke and Raynaud, 1997; Blanke et al., 1999) to track water parcels from major river mouths. Even though Ariane only uses advection scheme tracking, with diffusion and mixing processes partly handled by the source (numerical model) velocity fields, it has been successful in tracing pathways of given water masses (Lique et al., 2010; Hu and Myers, 2013; Gillard et al., 2016; de Boisséson et al., 2012).

In this study, Ariane particles were released in January 2004, and tracked until December 2016 in the CTRL simulation. Particles were released along the coastline where runoff forcing is applied. Our results are based on releasing 50 particles per runoff grid cell in the top $10 \mathrm{~m}$ of the water column, so as to mimic how runoff is dealt with in the model. Therefore, rivers with more discharge have more runoff grid cells and thus more Lagrangian floats are released.

\subsection{Ocean hydrological observations}

To evaluate the model simulations, we used observations comprised of ArcticNet cruise data (2005, 2006, 2007, and 2010 cruises; http:// www.arcticnet.ulaval.ca/), Marine Environmental Data Service (MEDS, now Oceanography and Scientific Data or OSD; url http://www.medssdmm.dfo-mpo.gc.ca/) data from 1929 to 2015, and ICES Dataset on Ocean Hydrography (International Council for the Exploration of the Sea. Accessed March 14, 2016. Copenhagen, 2014. http://www.ices. dk) data from 1929 to 2016. Duplicate data in the dataset collection were removed.

Sea surface temperature (SST) data used is satellite data from the Optimum Interpolation SST (OISST) Version 2 dataset (Reynolds et al., 2007) which are available from the National Oceanic and Atmospheric Administration (NOAA) Earth System Research Laboratory Physical Science Division (ESRL/PSD). The spatial resolution of this dataset is $0.25^{\circ}$ and is based on the combination of the Advanced Very High Resolution Radiometer (AVHRR) infrared satellite and SST observations from ships and buoys.
Ocean velocities were evaluated against altimeter products, absolute geostrophic velocity, produced by Ssalto/Duacs and distributed by Aviso with support from Cnes (http://www.aviso.altimetry.fr/duacs/). These data were available daily with a $1 / 4^{\circ}$ spatial resolution.

\subsection{Ice observations}

We evaluated simulated sea ice drift through comparison with the low-resolution sea ice drift product of the EUMETSAT Ocean and Sea Ice Satellite Application Facility (OSI-SAF, www.osi-saf.org). With a spatial resolution of $62.5 \mathrm{~km}$, and time lapse of twodays, the OSI-SAF sea ice drift product combines data from daily maps of satellite signals, including brightness temperatures from passive microwave sensors, or radar backscatter from scatterometers (Lavergne et al., 2015). Uncertainty in zonal and meridional displacements is on the order of $2.5 \mathrm{~km}$.

Sea ice thickness observations were obtained for the period November 2010-April 2016 from a combination of Cryosat-2 Synthetic Aperture Interferometric Radar Altimeter (SIRAL) Baseline C data and Soil Moisture and Ocean Salinity (SMOS) L-band radiometer data. The full processing chain for deriving and merging these thickness products for the HBC region is provided in Landy et al. (2017).

Simulated ice concentrations were compared to ASI Algorithm AMSR-E/AMSR2 sea ice concentration, which were obtained for 2002-2015 from the Institute of Environmental Physics (https://seaice. uni-bremen.de/sea-ice-concentration/), University of Bremen, Bremen, Germany (Spreen et al., 2008). AMSR-E data is used from January 2004 to October 2011, and AMSR2 data is used from July 2012 to December 2015. AMSR-E/AMSR2 ice concentration data has a horizontal resolution of $6.25 \mathrm{~km}$ and a temporal resolution of 1 day.

\subsection{Reference salinity}

We use a reference salinity of 33 for our freshwater calculations as this is the most saline layer in Hudson Bay and has been used by earlier studies (St-Laurent et al., 2011; Granskog et al., 2007; Prinsenberg, 1984). The freshwater fluxes are the product of the area of the side of the grid cell, the perpendicular velocity, and the grid cell's freshwater concentration, defined as

$F W=\frac{S_{r e f}-S}{S_{\text {ref }}}$

where FW is the freshwater concentration. The reference salinity is represented by $S_{\text {ref }}$ which we use 33, and the seawater salinity as $S$.

\section{Results}

\subsection{Model evaluation}

To evaluate the model, we first show spatial SST for the model and observations in Fig. 4a-j for both summer and fall. During the winter (January, February, March) and spring (April, May, June), the simulated SSTs are close to the freezing point (not shown) since the bay is ice covered. In fall, simulated SSTs (Fig. 4a-d) agree very well with observations (Fig. 4e). The temperature gradient from north to south in Hudson Bay is captured well by all simulations. Most simulations are too cold along the northern coast of Hudson Strait, as well as along the western coast of Foxe Basin, compared to observations.

In summer, the general pattern of the simulated SST tends to follow the observed SST pattern, with higher temperatures in James Bay and lower temperatures in northern Hudson Bay, Hudson Strait, and Foxe Basin (Fig. 4f-j). There are some inconsistencies as well. On the large scale, simulations show colder SSTs compared to observations, such as in central Hudson Bay where SSTs are approximately $3^{\circ} \mathrm{C}$ colder than observations in all simulations, due to the heat flux associated with 


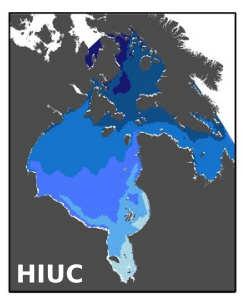

(a)

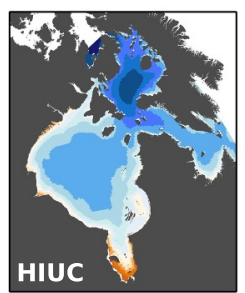

(f)

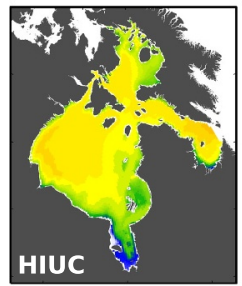

(k)

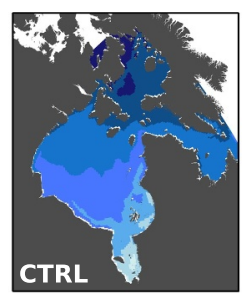

(b)

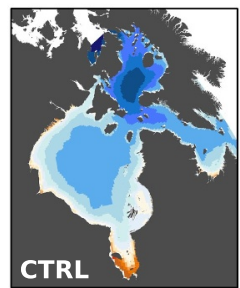

(g)

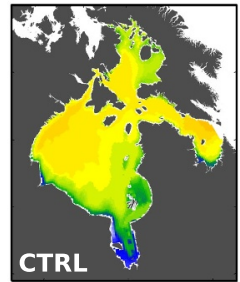

(1)

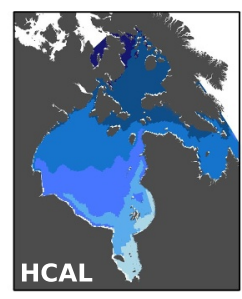

(c)

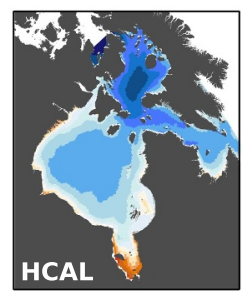

(h)

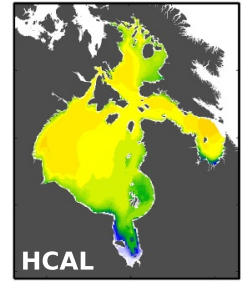

(m)

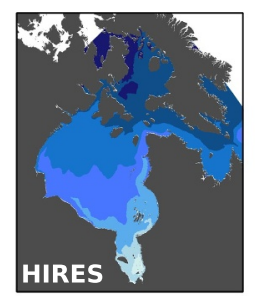

(d)

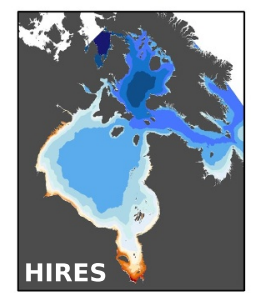

(i)

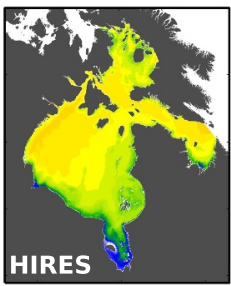

(n)

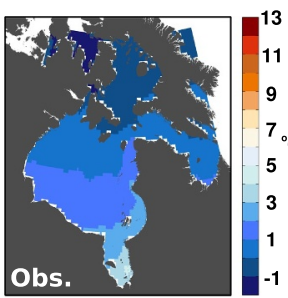

(e)

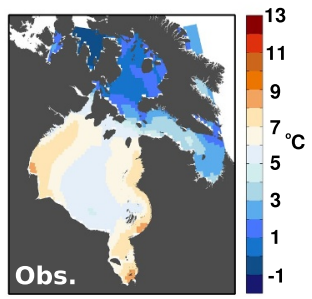

(j)

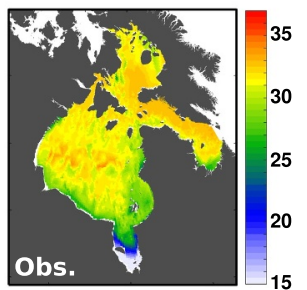

(o)
Fig. 4. Fall (October, November, December) SST for four model experiments (a) HIUC, (b) CTRL, (c) HCAL, (d) HIRES, and (e) observations. Summer (July, August, September) SST for four model experiments (f) HIUC, (g) CTRL, (h) HCAL, (i) HIRES, and with observations shown in (j). The bottom panel shows top $100 \mathrm{~m}$ mean salinity for August 2004-2016 for model experiments (k) HIUC, (l) CTRL, (m) HCAL, and (n) HIRES, and in (o) available gridded July-September observations.
CGRF atmospheric forcing. Moreover, the coastal areas in northwestern and southwestern Hudson Bay, and in southern James Bay and Ungava Bay, show higher temperatures in all simulations compared to observations. Along the eastern shore of Hudson Bay, all simulations are colder than observations, with the exception of northeast of the Belcher Islands.

Fig. $4 \mathrm{k}-\mathrm{o}$ shows the spatial distribution of the top $100 \mathrm{~m}$ averaged salinity for observations and four experiments. Observations from July-September are shown, while only August is shown for model experiments. This was done because the majority of observations were taken in August (450,000 measurements from all depths), but a significant number of observations were taken in July and September (25,000 and 200,000 measurements respectively), which were included for more spatial coverage. All four model experiments capture the higher salinities in the center of Hudson Bay, western Foxe Basin, and the northern coast of Hudson Strait. The experiments also reproduce the low salinities observed along the southern coast of Hudson Bay, and in James Bay. Smaller features, such as low salinities east of the Belcher Islands, north of Inukjuak, eastern Foxe Basin, and southern Ungava Bay are also captured by the experiments.

Data from an ArcticNet Cruise in September 2006 (http://www. arcticnet.ulaval.ca/) were used to compare a west-east cross section in Hudson Bay with the model simulations (Fig. 5). Observations show warmer surface temperatures and cooler temperatures at depth (Fig. 5e) compared to all model simulations (Fig. 5a-d). This could be due to an issue with the air-sea fluxes or that the model uses 5-day averages, instead of single point measurements at a given time. Another possible explanation for this discrepancy is that the model overestimates vertical mixing. All model simulations show warmer surface temperatures along the coast, which is not available in the observations. The depth of the mixed layer in model simulations, around $40 \mathrm{~m}$, is close to the observed mixed layer depth seen in Fig. 5e. The transition between the warm surface waters and the cooler waters at depth is more abrupt in observations compared to the model simulations as well.

Fig. $5 \mathrm{f}-\mathrm{i}$ shows salinity along the same west-east cross section in
Hudson Bay for the HIUC, CTRL, HCAL, and HIRES simulations. Bathymetry is different in the HIRES simulation due to the higher resolution. Three of the four simulations show salinities higher than 33.5 at the bottom, while the HCAL experiment and observed salinities do not exceed this value. In 5-day mean model output, salinities at the surface are also higher than observations, with closer agreement towards the east coast. The model captures the isohaline slopes at intermediate depths very well, which are generally at comparable depths to observations.

Aviso geostrophic currents in Fig. 6 (red) are compared to simulated geostrophic velocities shown in yellow. All simulations show weaker geostrophic velocities in central Hudson Bay compared to the Aviso geostrophic velocities. In all cases, flow along the southern coast of Hudson Strait is stronger in the model than observations, as well as along the western Hudson Bay coast. This discrepancy could partly be explained by Aviso's coarse resolution.

The HBC ice concentration seasonal cycle is shown in Fig. 7a. Simulated ice concentration is less than observed in the first three months of the year, for all experiments. The HIRES experiment has the best agreement with observations for January-May. During the melt season, ice concentrations are up to $5 \%$ lower than observations, while during the ice growth season in the fall, simulated ice concentrations are significantly lower, particularly in December with an ice concentration difference of over $30 \%$. This discrepancy can be explained by the late ice formation in the fall in our model configuration. This late ice formation is also seen in the seasonal cycle of ice thickness (Fig. 7b), where we have differences of over $20 \mathrm{~cm}$ in December, with all simulations underestimating ice thickness to the same degree. Underestimations of ice thickness continue to occur throughout the winter, however the difference between observations and the model simulations decreases in March and April. The two simulations using the DT runoff have marginally thicker ice in March compared to the two simulations that use the HYPE discharge datasets.

We focus on the model skill in capturing the sea ice growth and melt periods. Fig. 8 (top panels) shows the mean ice concentration for 


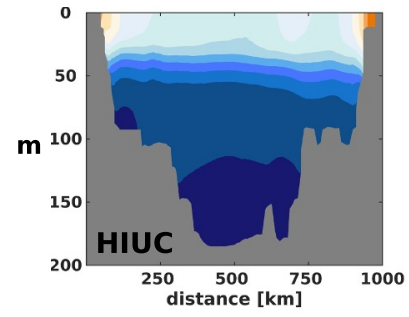

(a)

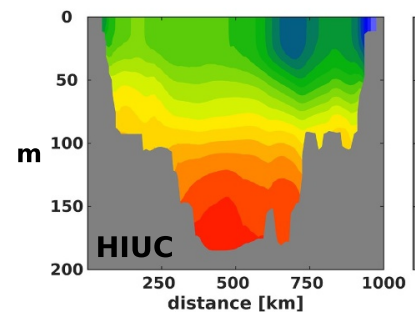

(f)

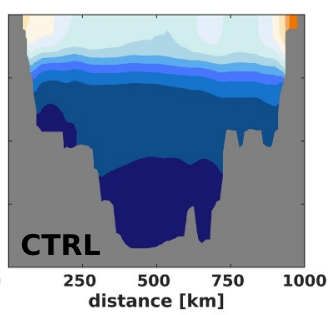

(b)

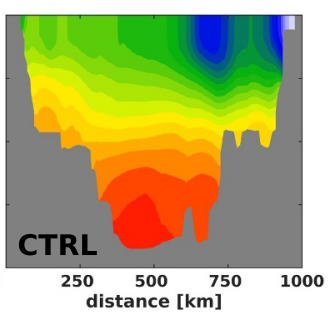

(g)

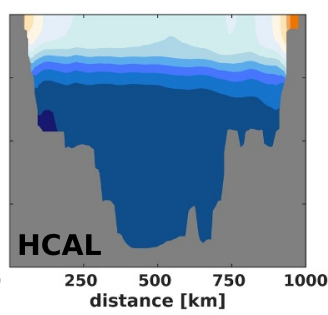

(c)

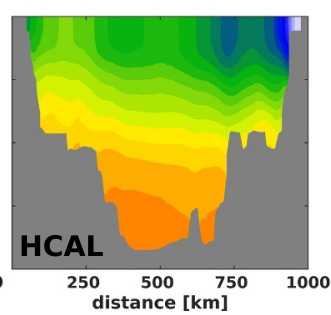

(h)

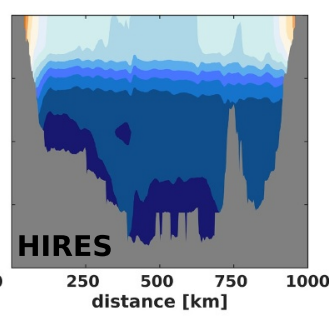

(d)

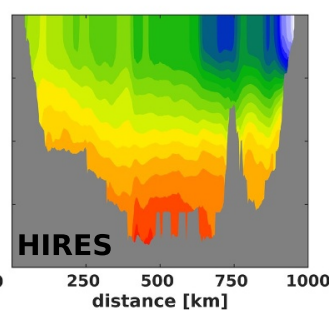

(i)

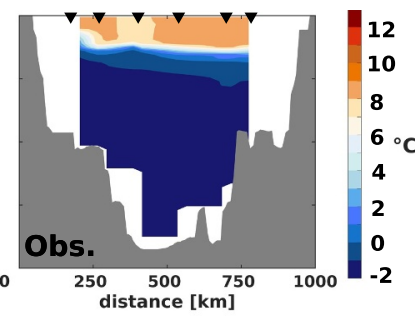

(e)

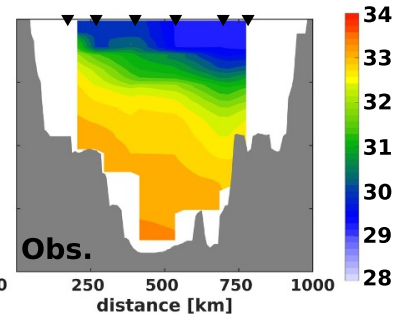

(j)

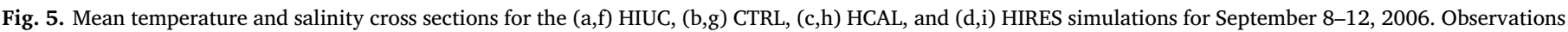

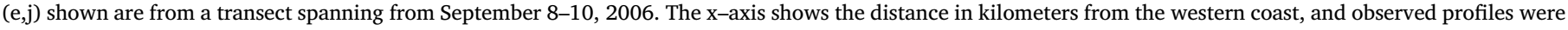
taken at the points marked with black triangles shown in Fig. 1.

April-June. Observations (Fig. 8e) show high ice concentrations in Foxe Basin during this time, which all model simulations capture. Observations show lower ice concentrations on the northern coast of Hudson
Strait, and higher concentrations along the southern coast, of up to $70 \%$. All model simulations show too much ice in Hudson Strait, and the north-south structure is not completely captured. During this time,

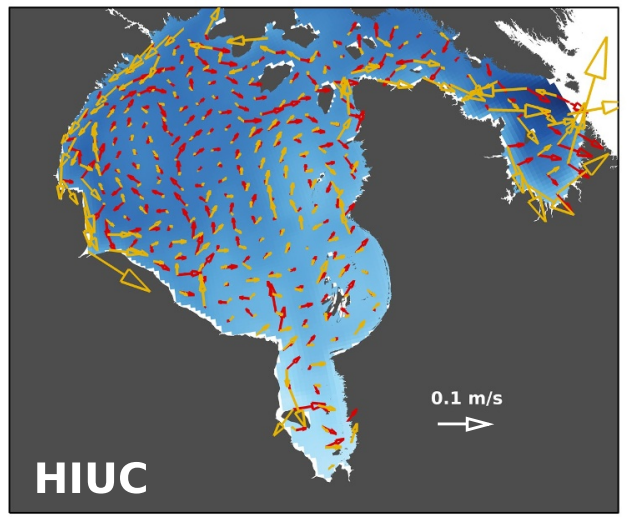

(a)

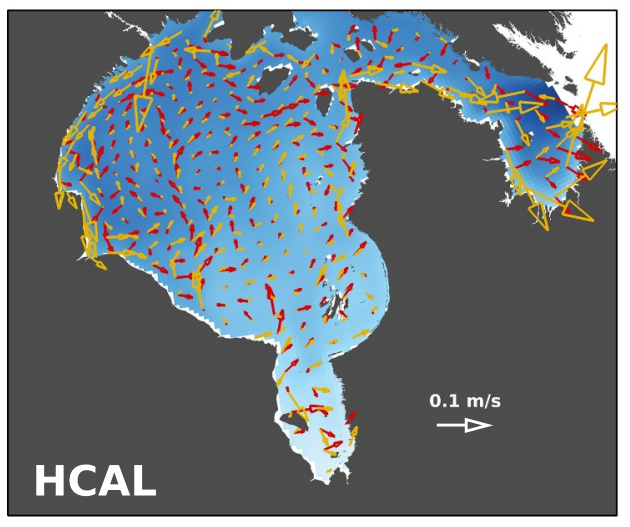

(c)

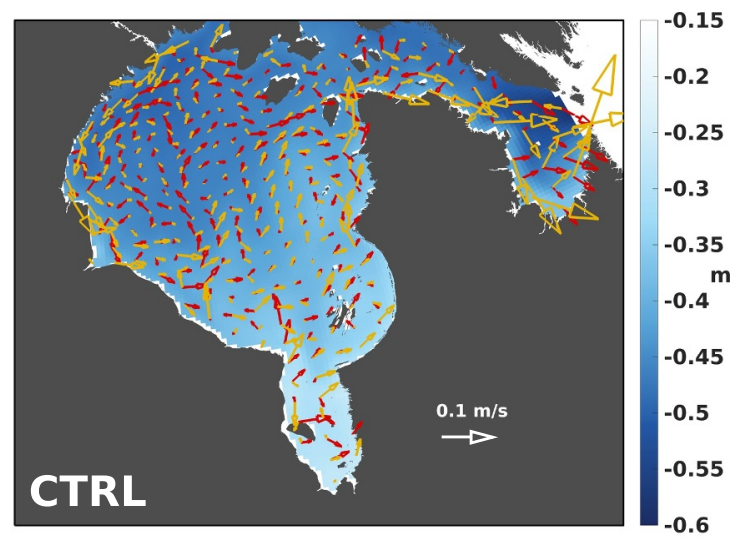

(b)

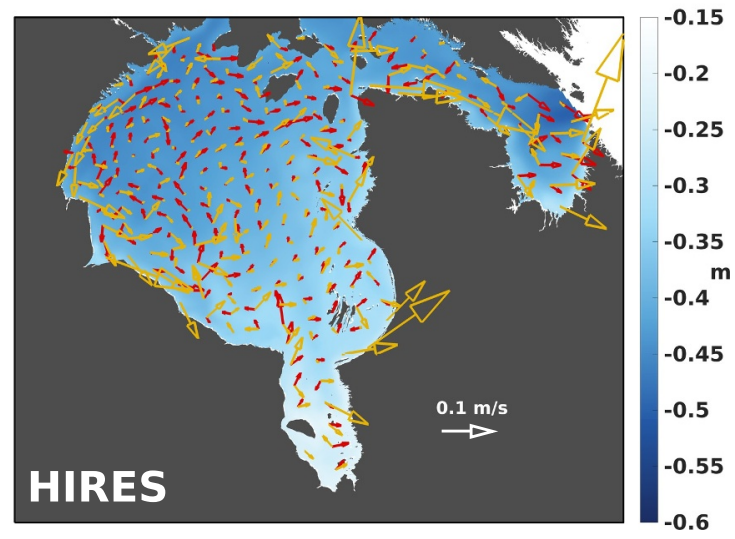

(d)

Fig. 6. Simulated July-September mean surface geostrophic velocities (yellow) and sea surface height with Aviso vectors in red for (a) HIUC, (b) CTRL, (c) HCAL, and (d) HIRES. Velocities, both observed and simulated, were averaged over 2004-2015. (For interpretation of the references to colour in this figure legend, the reader is referred to the web version of this article.) 


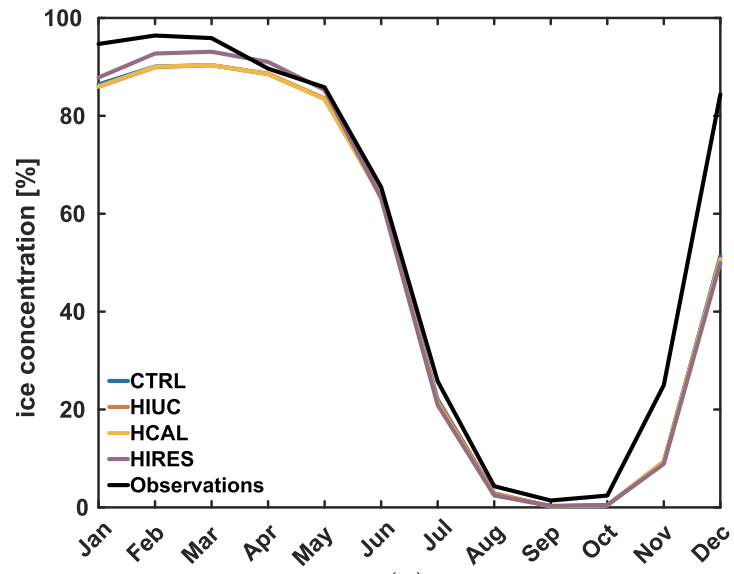

(a)

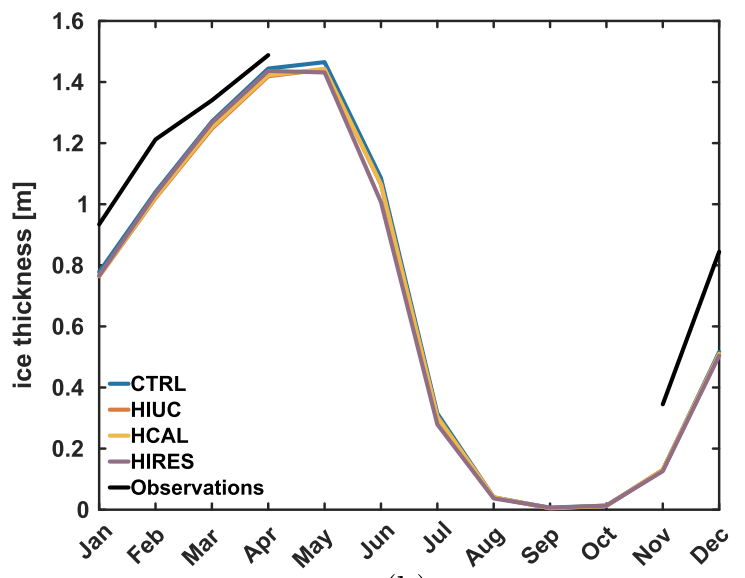

(b)

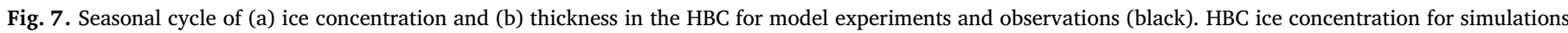
and AMSR-E/AMSR2 observations is averaged over 2004-2015, while for ice thickness, simulations and observations were averaged over 2011-2015.

high ice concentrations (up to 95\%) are still observed in central Hudson Bay, which is generally reproduced by the simulations as well. Finally, although with relatively high ice concentrations, the model is able to simulate the observed low ice concentration pattern (i.e., in James Bay, along the southern and eastern coasts) as well as the high ice concentration in the northwest corner of James Bay. The ice concentration within James Bay is overestimated, particularly in the $1 / 4^{\circ}$ simulations. It is likely attributed to the bias in local sea ice advection.
Ice concentrations during the ice growth season, from October-December, are shown in Fig. $8 \mathrm{f}-\mathrm{j}$. As has been stated previously, the late ice formation in our model simulations is a known issue. Ice concentrations in Foxe Basin are well simulated in all model experiments. Hudson Strait has ice concentrations that are higher than observations, especially near its eastern gate, but overall model simulations are comparable to observations in this region. Larger differences between the model and observations occur in Hudson Bay. Higher ice

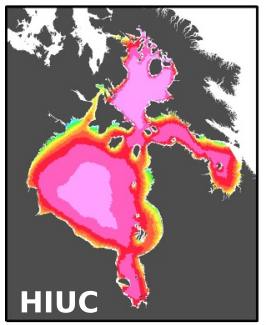

(a)

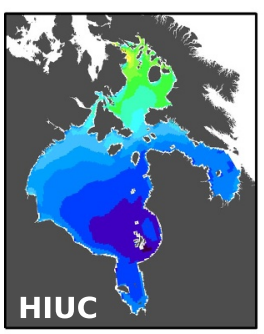

(f)

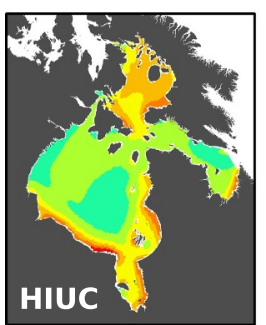

(k)

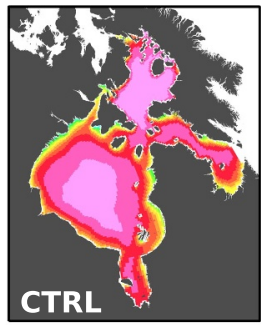

(b)

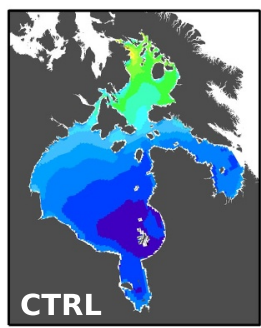

$(g)$

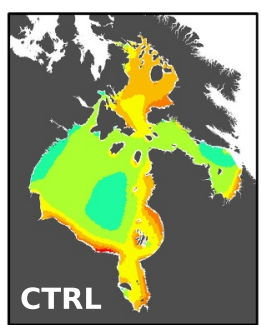

(1)

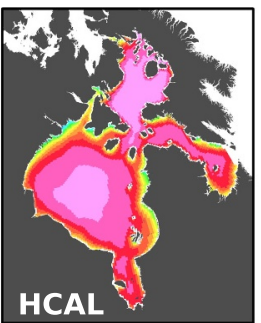

(c)

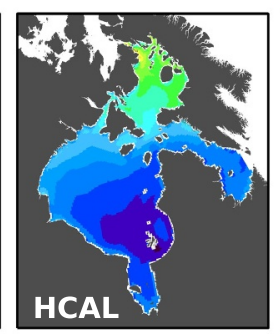

(h)

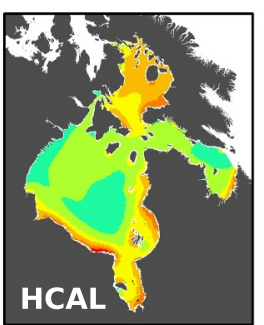

(m)

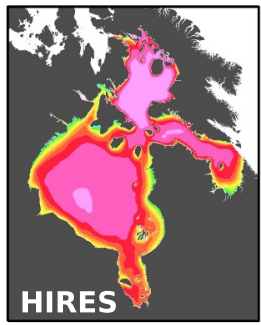

(d)

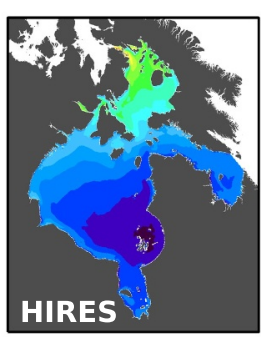

(i)

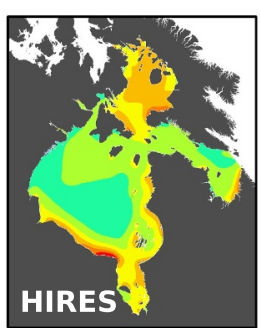

(n)

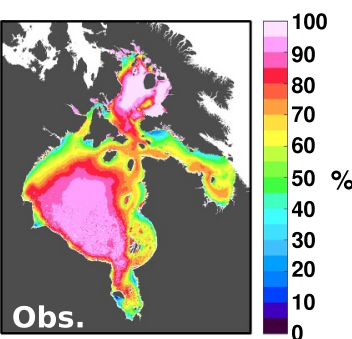

(e)

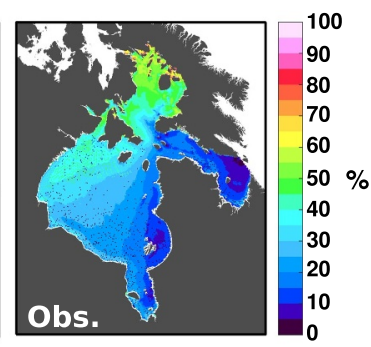

(j)

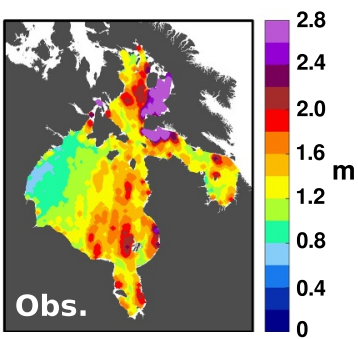

(o)

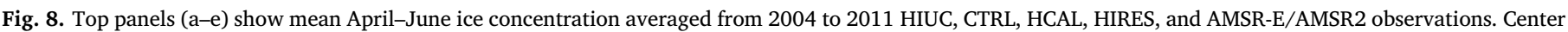

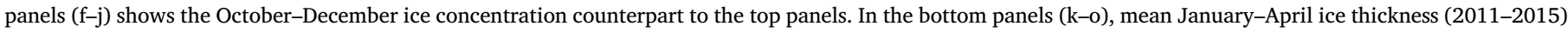
for HIUC, CTRL, HCAL, HIRES, and observations. 
concentrations, between 40 and 50\%, in northwestern Hudson Bay are not captured, as well as the higher concentrations across the bay, which is due to late freeze up in the model. However, the progression of ice concentrations across the bay from east to west is captured by the model simulations.

Spatial ice thickness is shown in Fig. 8k-o for the months January-April. The model is able to reproduce thinner ice in western Hudson Bay where there is a recurrent polynya. All experiments show thicker ice in eastern relative to western Hudson Bay, specifically east of the Belcher Islands. The observations show thicker ice from the center of the bay to the eastern coast, of which all experiments are not able to simulate. Additionally, thicker ice in the interior, between 1.5 and $2 \mathrm{~m}$, is not captured as simulated ice thickness ranges from 0.8 to $1.2 \mathrm{~m}$. Thicker ice along the eastern coast of Ungava Bay is captured by all experiments, with approximately the same magnitude. Ice thickness in Hudson Strait is simulated well, with the exception of the northwestern portion, where observations show ice thickness exceeding $2.5 \mathrm{~m}$. In Foxe Basin, thick ice is located in the eastern region in observations, the location of which was captured in the model experiments. However, simulated ice thickness is up to $1 \mathrm{~m}$ thinner compared to observations.

Next we show the ice thickness distributions (ITDs) in Hudson Bay for January-April (Fig. 9a-d), with observations shown in grey. All model simulations are unable to simulate the width of the ITD in observations, to compensate for this, the peak fraction of the ice thickness is higher than observations. We will note that the simulated peak ice thickness is close to the peak ice thickness in the observations. The

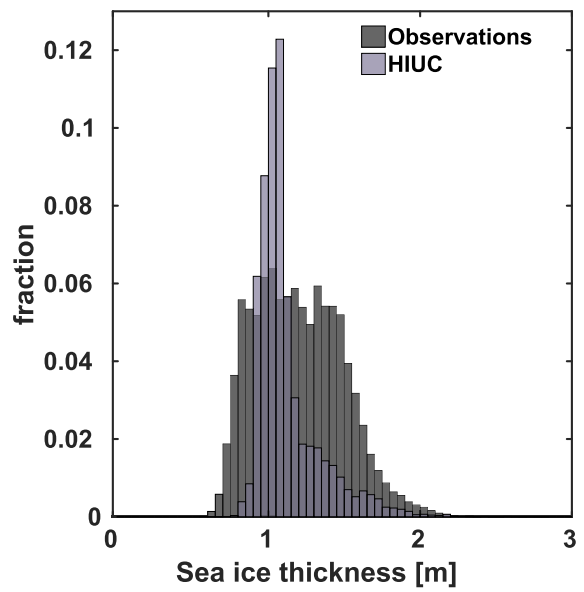

(a)

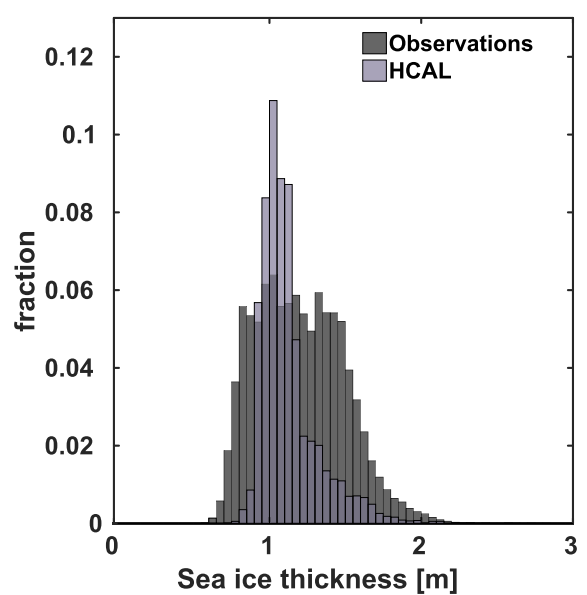

(c)
Table 1

Liquid freshwater equivalent ( \pm 1 standard deviation) contained in HBC sea ice in April (2004-2015) in units of $\mathbf{k m}^{3}$.

\begin{tabular}{ll}
\hline Experiment & $\mathrm{V}_{f w} \pm 1 \sigma$ \\
\hline HIUC & $1306 \pm 112$ \\
CTRL & $1323 \pm 112$ \\
HCAL & $1300 \pm 107$ \\
HIRES & $1285 \pm 115$ \\
Landy et al. (2017) & $1253 \pm 15$ \\
\hline
\end{tabular}

HIUC simulation shows lower fractions of thicker ice from January-April, compared to the other experiments, however the fractions of the peak ice thickness are larger. The CTRL experiment has higher fractions of ice thickness around the mode compared to HIRES, indicating the role of small scale processes in producing thinner ice.

The amount of freshwater stored in ice is important for the seasonal freshwater budget. Following Landy et al. (2017) with a constant sea ice salinity of 6 , we calculated the freshwater stored in sea ice in April averaged over 2004-2015 (Table 1). Our results agree very well with their observational estimate, with all simulations within $70 \mathrm{~km}^{3}$ of the observational estimate. CTRL contains the most freshwater in sea ice in April, while HIRES contains the least, which agrees best with observations, indicating the importance of resolution. Volume of runoff, as well as the timing and location of its release in the bay impacts the volume of freshwater in ice, as both HCAL and HIUC have less runoff

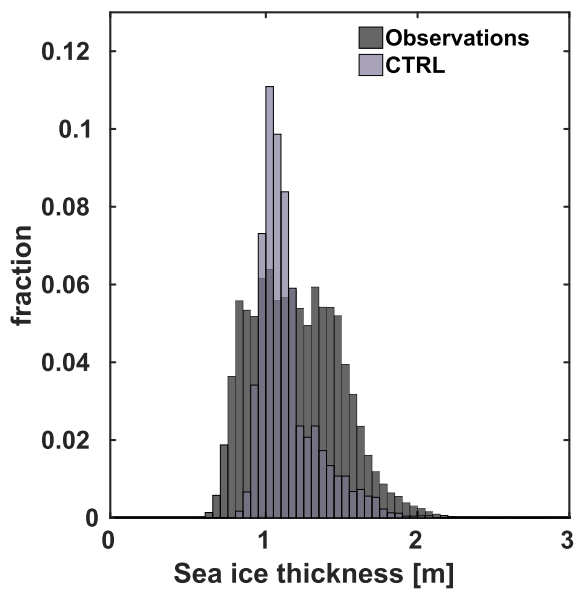

(b)

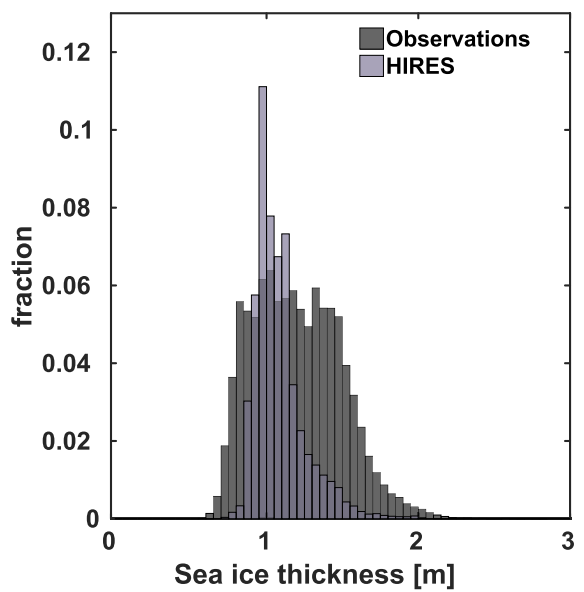

(d)

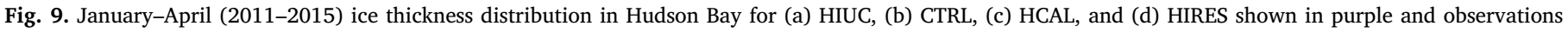
shown in grey. (For interpretation of the references to colour in this figure legend, the reader is referred to the web version of this article.) 


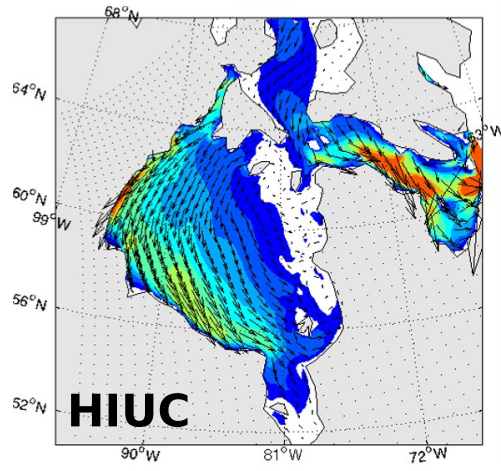

(a)

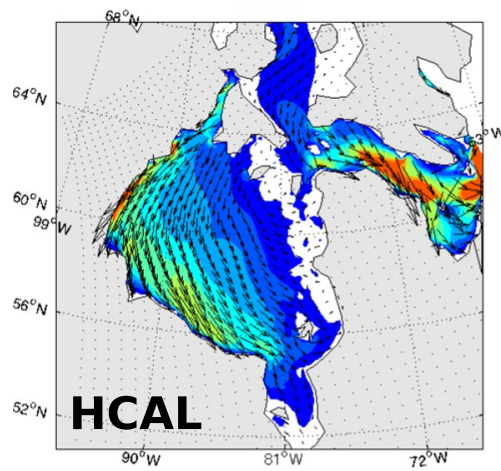

(c)

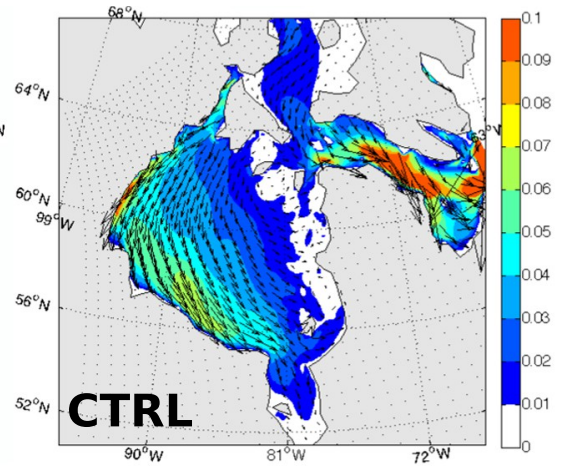

(b)

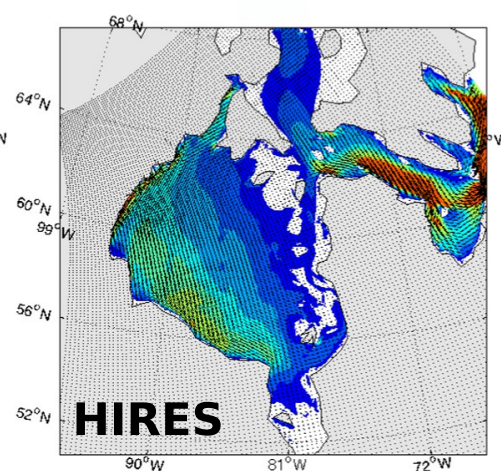

(d)

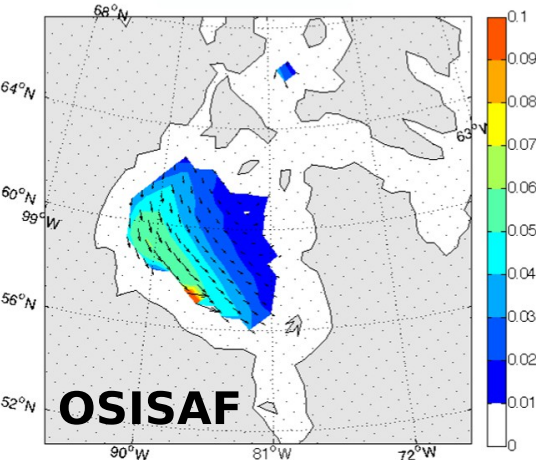

(e)

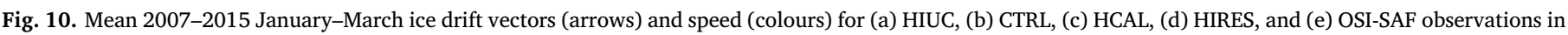
units of $\mathrm{m} / \mathrm{s}$.

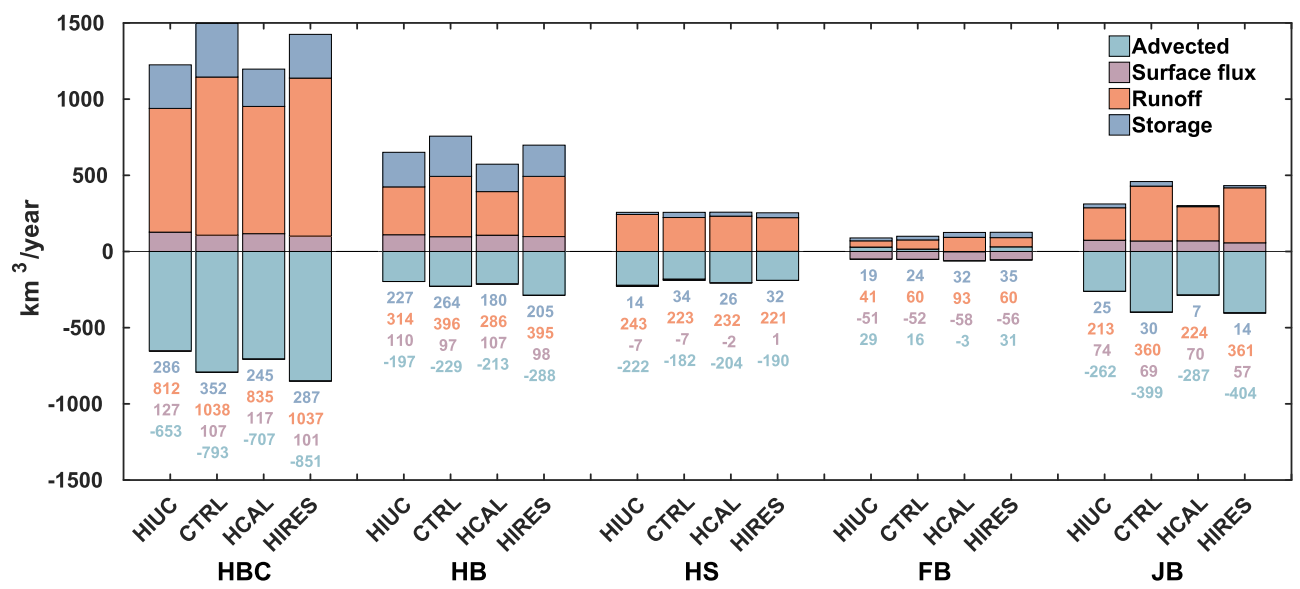

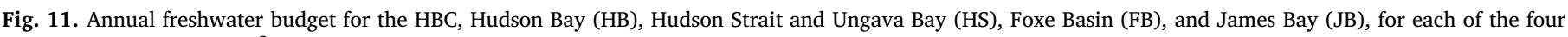
experiments. Units are $\mathbf{~ k m}^{3}$ per year, with a reference salinity of 33. Time period is 2004-2016.

than CTRL and thus have a lower volume of freshwater in ice. However, the HCAL simulation receives more discharge than HIUC, yet HIUC contains more freshwater in the ice.

We compare simulated ice drift to the OSI-SAF observational dataset (Fig. 10). General sea ice circulation features are captured by all model simulations, with regional differences in ice drift patterns (Fig. 10). An evaluation of root mean square error (RMSE) and bias (not shown) shows northwest/southeast asymmetry in drift and error distribution, comparable to Saucier et al. (2004).

Based on the above model evaluation, we acknowledge the larger model-observation discrepancies in sea ice in fall, however, we find overall, with the volume of equivalent freshwater in sea ice in April as well as the spatial distribution of ice concentration and thickness in the bay, that the model is able to capture and simulate the main features of the sea ice. Similarly, oceanographic variables, such as temperature, salinity, and velocities, are also reasonably simulated.

\subsection{HBC annual freshwater budget}

The freshwater budget for the HBC and its subregions takes the form

$\Delta F W$ storage $=\int_{t_{1}}^{t_{2}}\left(F W_{\text {adv }}+F W_{\text {surf }}+R\right) d t$

where $\Delta F W$ storage is the freshwater storage change between time $t_{1}$ and $t_{2} ; F W_{a d v}$ is the lateral freshwater flux, the sign of which depends on both salinity and the direction of the flow; $F W_{\text {surf }}$ is the freshwater input 


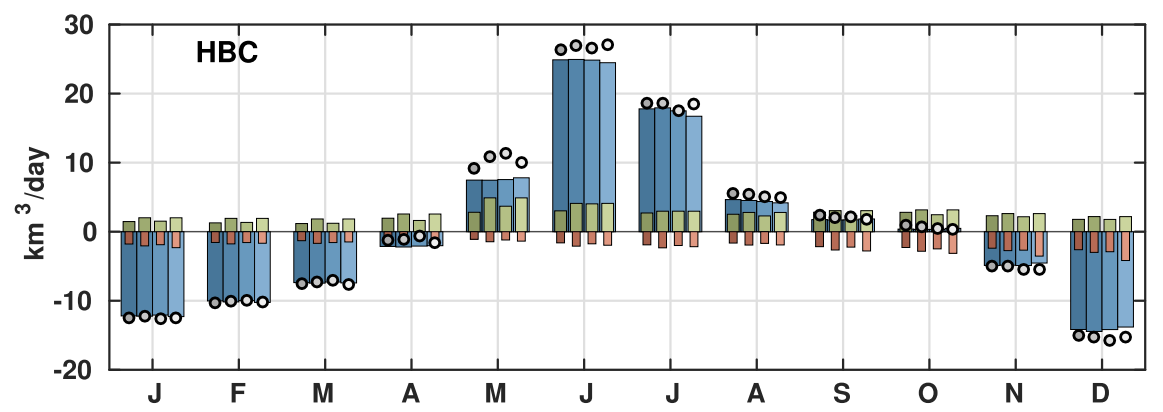

(a)

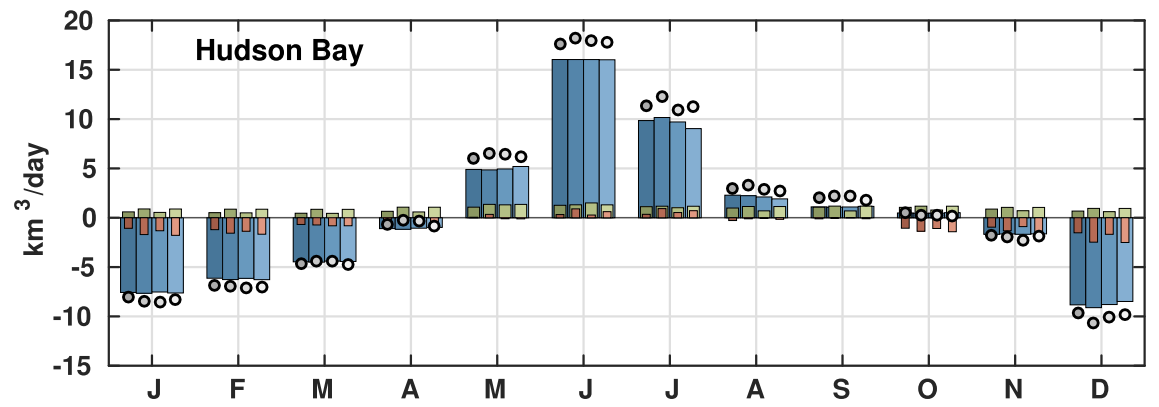

(b)

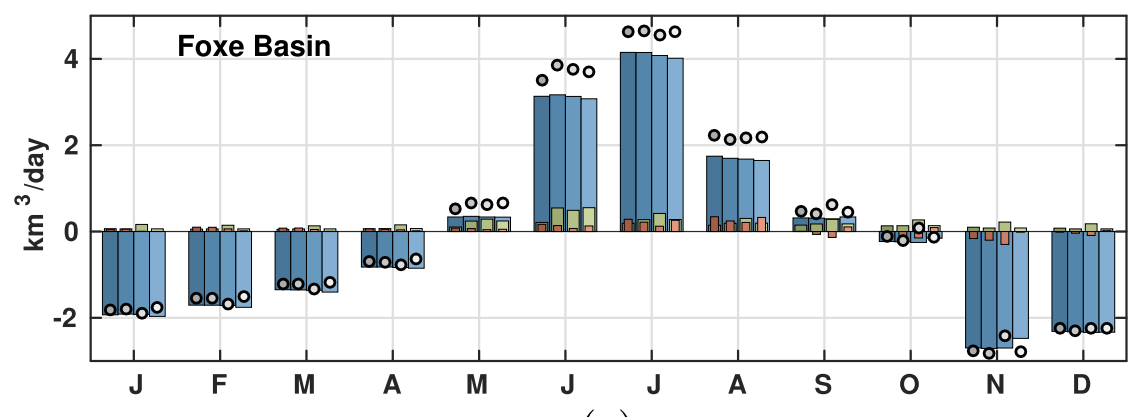

(c)

Fig. 12. Seasonality of the freshwater budget terms (2004-2016) for four experiments in each region, (a) HBC, (b) Hudson Bay, (c) Foxe Basin, (d) Hudson Strait, and (e) James Bay. A map showing the definition of each region is shown in (f) with various gates indicated. Each term in the freshwater budget is shown by a different colour, with blue bars showing surface fluxes, river runoff as green bars, red bars as advected freshwater, and grey circles showing the change rate of freshwater storage in each basin. Experiments are ordered as HIUC, CTRL, HCAL, and HIRES (darkest to lightest shade) from left to right in each set of bars.

Gates are indicated in (f) with back dashed lines. Abbreviations for each gate are as follows: FHS for Fury and Hecla Strait, RWS for Roes Welcome Sound, SI-BI gate for Southampton Island-Baffin Island gate, SI-QC gate for Southampton Island-Quebec gate, and HS east gate for Hudson Strait east gate. (For interpretation of the references to colour in this figure legend, the reader is referred to the web version of this article.)

(due to precipitation minus evaporation and sea ice growth/melt) at the ocean surface; $R$ is the runoff, a source of freshwater. For the purposes of this paper, negative fluxes are defined as leaving the region, and positive fluxes as entering the region, unless otherwise specified.

\subsubsection{Impact of runoff on surface and lateral fluxes}

Annual freshwater budgets for the HBC and its subregions were calculated for the three $1 / 4^{\circ}$ experiments, and are shown in Fig. 11. The $\mathrm{HBC}$, as a whole, receives about $22 \%\left(200 \mathrm{~km}^{3} / \mathrm{yr}\right)$ more runoff in CTRL compared to the HIUC experiment. The HIUC discharge dataset has less runoff entering the HBC in all months, especially during peak runoff in spring and early fall (Fig. 12a). The one exception is Hudson Strait, where the HIUC dataset is larger than the DT dataset by $8 \%\left(20 \mathrm{~km}^{3}\right.$ / yr). The HCAL experiment has about $3 \%\left(20 \mathrm{~km}^{3} / \mathrm{yr}\right)$ more runoff entering the HBC as a whole compared to HIUC. However, separating into subregions shows that CTRL has the least amount of runoff entering Hudson Strait, followed by HCAL and HIUC. In Hudson Bay, HCAL has $28 \%\left(110 \mathrm{~km}^{3} / \mathrm{yr}\right)$ less runoff than CTRL. Foxe Basin, on the other hand, has the most discharge in the HCAL simulation, $35 \%\left(30 \mathrm{~km}^{3} / \mathrm{yr}\right)$ and $56 \%\left(50 \mathrm{~km}^{3} / \mathrm{yr}\right)$ more than the CTRL and HIUC experiments respectively. Lastly, the DT dataset has the most runoff in James Bay of $360 \mathrm{~km}^{3} / \mathrm{yr}$, compared to both HYPE products which have 213 and 224 $\mathrm{km}^{3} / \mathrm{yr}$ for HIUC and HCAL accordingly.

Surface fluxes are larger in the HBC, as a whole, in the HIUC experiment, followed by HCAL. The separate basins show higher net surface fluxes in Hudson Bay $\left(13 \mathrm{~km}^{3} / \mathrm{yr}\right.$ or $\left.12 \%\right)$ and James Bay (5 $\mathrm{km}^{3} / \mathrm{yr}$ or $7 \%$ ) in the HIUC simulation compared to CTRL, with no change in Hudson Strait surface fluxes. Surface fluxes in Hudson Bay in HCAL are similar to HIUC, while HCAL surface fluxes in James Bay are comparable to CTRL. Of the $1 / 4^{\circ}$ simulations, HCAL has the lowest magnitude of surface fluxes, at $-2 \mathrm{~km}^{3} / \mathrm{yr}$ in Hudson Strait. Foxe Basin surface fluxes show little change between the CTRL and HIUC experiments, while HCAL has the largest net negative surface flux.

Advected freshwater out of the HBC, as a whole, is $18 \%\left(140 \mathrm{~km}^{3}\right.$ / yr) larger in the CTRL experiment than HIUC. This is also the case for freshwater advection in both Hudson and James Bays, with 21\% (82 $\left.\mathrm{km}^{3} / \mathrm{yr}\right)$ and $41 \%\left(147 \mathrm{~km}^{3} / \mathrm{yr}\right)$ more river discharge per year respectively. Advected freshwater in the HCAL simulation falls between CTRL 


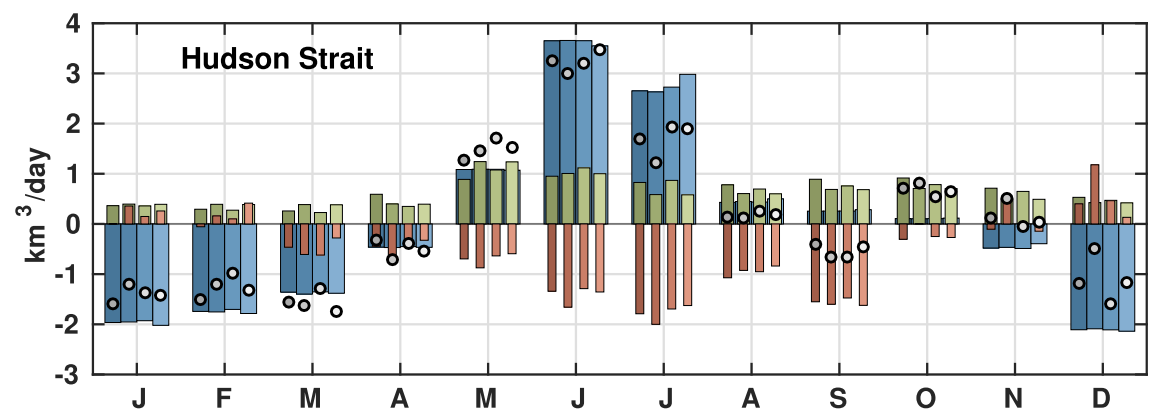

(d)

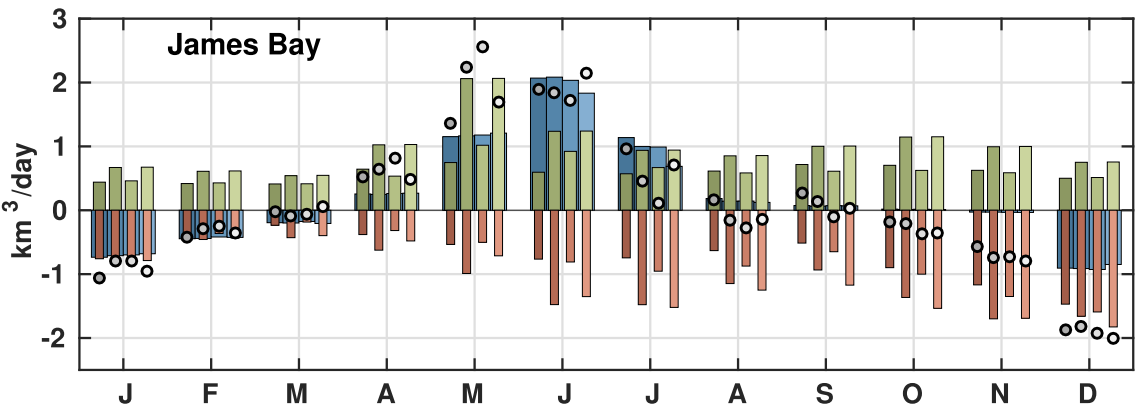

(e)

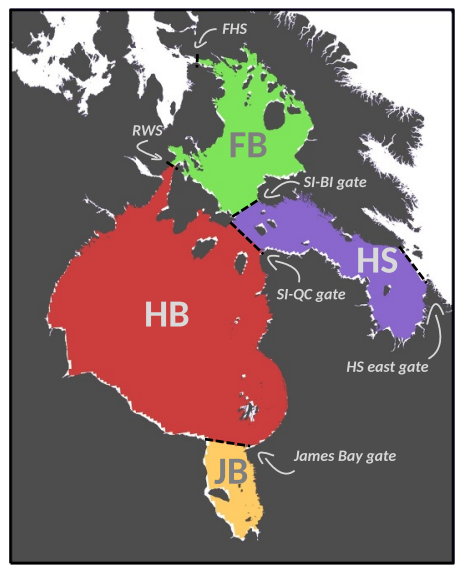

(f)

Fig. 12. (continued)

and HIUC for Hudson Bay, and the HBC as a whole. Advection in James Bay for HCAL is $9 \%\left(25 \mathrm{~km}^{3} / \mathrm{yr}\right)$ larger than HIUC, with CTRL having even more advected freshwater out of the shallow bay. On its own, Hudson Strait has more freshwater advection out of the strait in HIUC, by $18 \%\left(40 \mathrm{~km}^{3} / \mathrm{yr}\right)$, than CTRL, due to less freshwater accumulation and more runoff, with HCAL falling in between. HCAL is the only simulation to have net advection out of Foxe Basin of the three $1 / 4^{\circ}$ experiments of $-3 \mathrm{~km}^{3} / \mathrm{yr}$, with the CTRL experiment advecting $45 \%$ $\left(13 \mathrm{~km}^{3} / \mathrm{yr}\right)$ less into the basin than the HIUC experiment. The sum of the advected freshwater, surface fluxes, and runoff, equals the changing rate of freshwater that is stored in each region. All simulations show freshening of the HBC and its subregions over time. CTRL has higher freshwater accumulation overall than HIUC and HCAL, with the exception of Foxe Basin, where HCAL has the highest freshwater storage of the $1 / 4^{\circ}$ experiments.

Fig. 12 shows the seasonality of each of the freshwater terms in the freshwater budget equation. In regions such as the HBC and Hudson Bay proper, surface fluxes are the dominant term throughout the year, with maxima in June and minima in December. In the HBC, advected freshwater and runoff are approximately in balance, with different runoff datasets having very little impact on the seasonality of advected freshwater (Fig. 12a). As Foxe Basin is farther north, peak surface fluxes occur in July (Fig. 12c) and are minimum in November, and like Hudson Bay proper, surface fluxes are the dominant term. The DT and HCAL datasets show a runoff peak in June in Foxe Basin, whereas, there is no clear peak in the HIUC runoff. This difference appears not to have a large impact on advected freshwater in the region, as peak net advection into the basin occurs in August in all simulations, with maximum freshwater export out of the basin occurring in November. Similar to the HBC seasonal cycle, Hudson Bay proper runoff and advected freshwater are roughly balanced during winter, with maximum freshwater export occurring in October and December for all experiments. However, during summer, freshwater export weakens and there is a net freshwater import into the bay. This occurs because of the large amount of freshwater that is advected out of James Bay (Fig. 12e) and into Hudson Bay. During the year, surface fluxes in both James Bay 


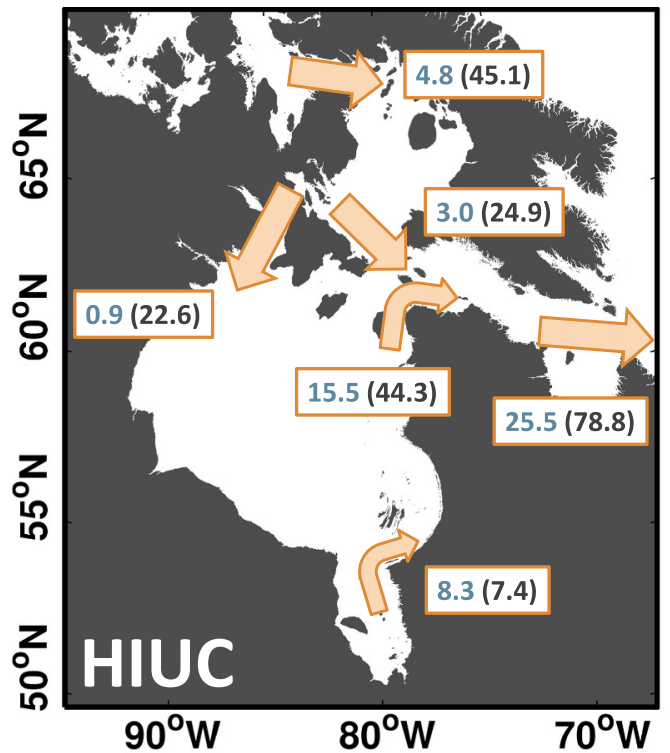

(a)

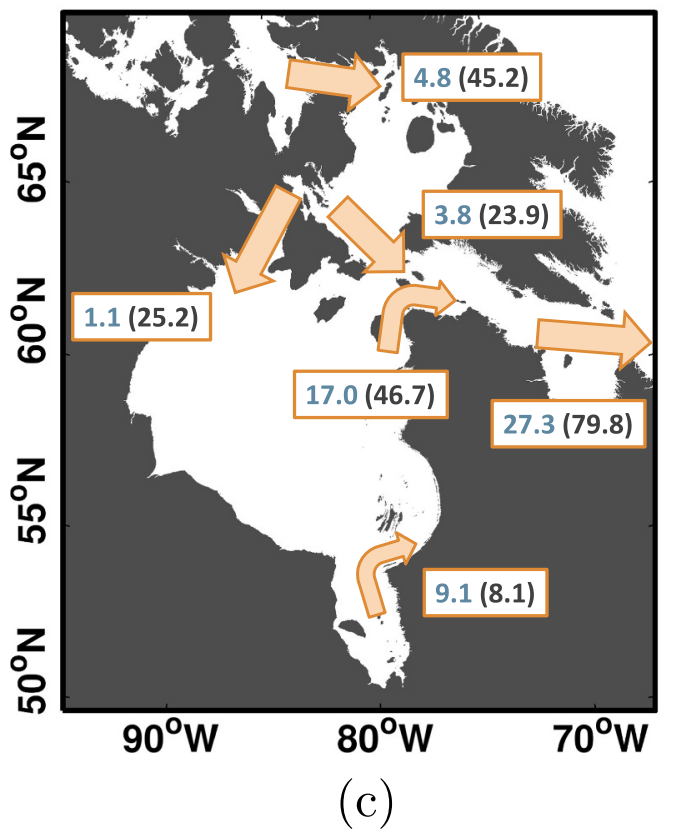

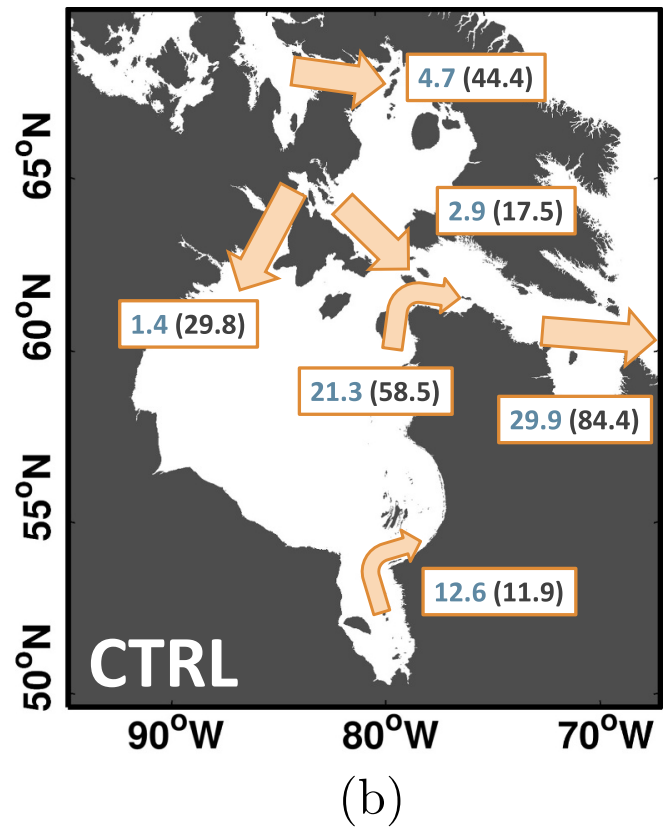

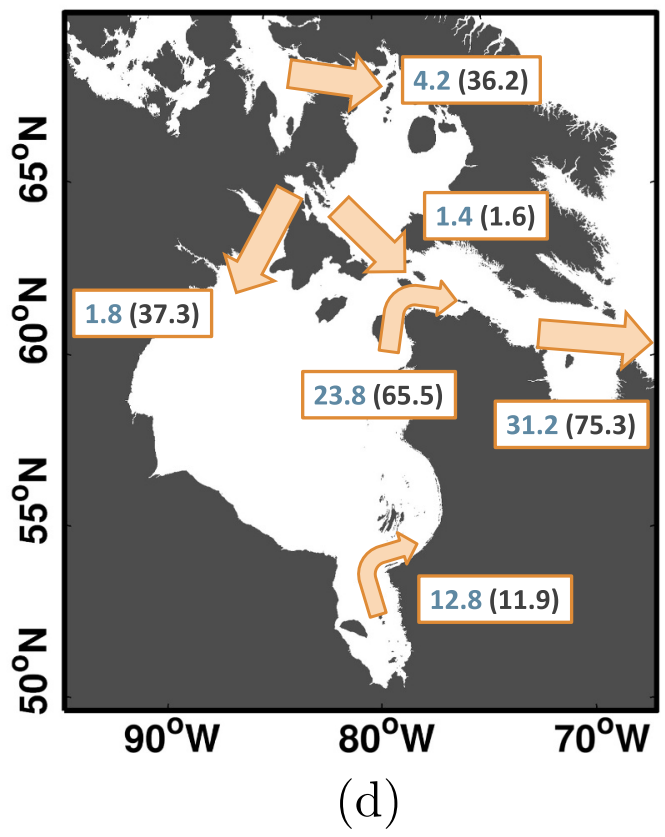

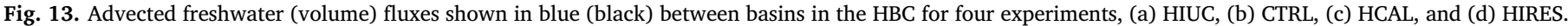

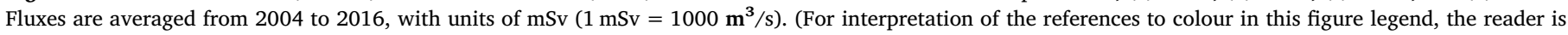
referred to the web version of this article.)

and Hudson Strait are not as dominant in the freshwater budget as the other basins (Fig. 12). Surface fluxes peak in June in both regions with minima in December and January for all experiments. Runoff seasonality in both basins is reduced in the HIUC experiment compared to CTRL, due to the more 'damped' seasonal cycle in the runoff dataset, with HCAL having more seasonality than HIUC, but less than CTRL. Advected freshwater in Hudson Strait varies between simulations, with CTRL advecting more than the other two $1 / 4^{\circ}$ experiments, likely due to the gap filled DT dataset, and is more noticeable in the winter months. Similarly, advected freshwater in James Bay is also reduced in HIUC and HCAL compared to the CTRL simulation throughout the year, due to the impacts of regulation included in the HYPE datasets. The advection is directly related to the runoff, with peak advection occurring one month later than peak runoff in both summer and fall. Peak runoff in CTRL causes maximum freshwater storage in May, one month earlier than both the HIUC and HCAL experiments. In this study, our focus is on the long term mean, however, investigating year-to-year variability in the freshwater budget would be an interesting topic for future work.

Fig. 13 shows the freshwater advection for each gate in the HBC for the four experiments (gates are indicated in Fig. 12f). Freshwater and volume transport through Fury and Hecla Strait are similar for the HIUC, HCAL, and CTRL experiments, while freshwater transport through Southampton and Baffin Islands are similar between the HIUC and CTRL experiments. The HCAL experiment has $0.1 \mathrm{mSv}$ more freshwater transport through this gate compared to the other two. Volume transport, on the other hand, varies, with CTRL having $7.4 \mathrm{mSv}$ less volume transport than HIUC through Baffin-Southampton Gate, while HCAL has $1 \mathrm{mSv}$ less transport compared to HIUC. Flow through 
Roes Welcome Sound is similar between HIUC and HCAL with regards to freshwater transport, but there is more volume transport, by $2.6 \mathrm{mSv}$, in HCAL. CTRL has a larger volume flux by $7.2 \mathrm{mSv}$ compared to HIUC, in addition to $0.5 \mathrm{mSv}$ more freshwater transport through the sound. Freshwater and volume fluxes through the Southampton-Quebec gate, James Bay, and eastern Hudson Strait are all smaller in the HIUC experiment compared to CTRL, which is due to the HIUC dataset having less runoff, as this dataset does not include regulation on the La Grande Riviere. Fluxes through the three eastern gates in the HCAL experiment fall between HIUC and CTRL. A detailed comparison of fluxes obtained here and available observations is presented in Section 4.

\subsubsection{Impact of model resolution on surface and lateral fluxes}

The CTRL and HIRES experiments have the same runoff forcing, and thus the same volume of runoff entering each region every year (Fig. 11). HIRES has more advected freshwater out of the HBC by roughly $7 \%\left(60 \mathrm{~km}^{3} / \mathrm{yr}\right)$. The difference leads to less, by roughly the same amount, freshwater storage in the HBC in the HIRES experiment, compared to CTRL. In the subregions, runoff and surface fluxes are similar in Foxe Basin, while advected freshwater (into Foxe Basin) is about twice as much as in CTRL. Thus, freshwater storage within Foxe Basin in HIRES is $31 \%\left(11 \mathrm{~km}^{3} / \mathrm{yr}\right)$ larger than in CTRL. In Hudson Strait, runoff is similar while advected freshwater is $4 \%\left(8 \mathrm{~km}^{3} / \mathrm{yr}\right)$ higher than CTRL. Surface fluxes are close to zero in HIRES, and are a freshwater source, whereas CTRL surface fluxes are a freshwater sink and have a magnitude of $7 \mathrm{~km}^{3} / \mathrm{yr}$. Freshwater storage in the strait is similar between the two runs, at $34 \mathrm{~km}^{3} / \mathrm{yr}$ in CTRL and $32 \mathrm{~km}^{3} / \mathrm{yr}$ in HIRES. Both surface fluxes and runoff are the same in Hudson Bay. Advected freshwater, however, is larger in the HIRES simulation compared to CTRL by $20 \%\left(60 \mathrm{~km}^{3} / \mathrm{yr}\right)$, leading to less freshwater storage in the HIRES simulation.

Fig. 12 (lightest shaded symbols) shows the freshwater seasonal cycle for all regions of the HBC for the HIRES simulation. The freshwater seasonal cycle of both the HBC, as a whole, Hudson Bay proper, and Foxe Basin is not largely impacted by increased resolution. Differences between experiments are more clearly seen in Hudson Strait (Fig. 12d) and James Bay (Fig. 12e). Advection into and out of Hudson Strait is generally smaller in all months (for the exception of February), with little advection in HIRES in December, while net freshwater import occurs in December in CTRL. James Bay freshwater advection is also diminished during the first part of the year, with increasing advection occurring in May/June and maximum summertime advection occurring in July, while CTRL has maintained peak advection through June and July. Advection is larger throughout the fall in HIRES compared to CTRL.

HIRES experiment fluxes between each region of the HBC are shown in Fig. 13d. Compared to CTRL (Fig. 13b), freshwater and volume fluxes in HIRES are similar from James Bay, but lower through Fury and Hecla Strait. Lower freshwater fluxes occur between Foxe Basin and Hudson Strait, with volume fluxes being largely reduced in HIRES to only $1.6 \mathrm{mSv}$ compared to $17.5 \mathrm{mSv}$ in CTRL. Fluxes through Roes Welcome Sound and between Southampton Island and Quebec are larger in HIRES than CTRL, in addition to higher freshwater fluxes out of Hudson Strait into the North Atlantic. Volume fluxes, however, were smaller than CTRL out of Hudson Strait.

\subsection{Boundary-interior exchange in Hudson Bay}

To investigate the processes involved in freshwater exchange between the boundary and interior regions in Hudson Bay, a boundary line based on the annual mean barotropic streamfunction is defined. To be more specific, we chose the contour of $-0.18 \mathrm{~Sv}\left(1 \mathrm{~Sv}=10^{6} \mathrm{~m}^{3} / \mathrm{s}\right)$ of the annual mean streamfunction (Fig. 14, top panels) for our analysis, as this was the largest value which was a closed contour in Hudson Bay in the HIRES simulation. The total freshwater and volume transport, in addition to the Ekman, turbulent, and mean flow contributions are shown in Fig. 14 for the four experiments. Ekman transports were calculated using:

$T_{E K y}=\frac{-1}{f \rho} \tau_{x} d x$

$T_{E K x}=\frac{1}{f \rho} \tau_{y} d y$

where $T_{E K x}$ and $T_{E K y}$ are the Ekman transports in the model grid $x$ and $y$ directions respectively. Grid cell width is denoted by $d x$ and $d y$ in the $x$ and $y$ directions respectively, $f$ is the Coriolis parameter, and $\rho$ represents density. Surface stress in the model grid $x$ and $y$ directions is given by $\tau_{x}$ and $\tau_{y}$ respectively. The freshwater transport due to Ekman transport is calculated by multiplying the Ekman volume transport with the freshwater concentration in the top $24 \mathrm{~m}$ (the nearest vertical level) based on Yang (2006). The total flow (v) can be decomposed into the mean and turbulent components. Here we assume the 5-day average model output as the total flow (v) and a running 25-day mean as the mean flow component $(\overline{\boldsymbol{v}})$. Thus the turbulent component is given by $\boldsymbol{v}^{\prime}=\boldsymbol{v}-\overline{\boldsymbol{v}}$.

On average, we see minimal turbulent freshwater exchange between the boundary and interior (Fig. 14, orange), while the mean component of the flow (yellow) contributes to the majority of freshwater exchanged, with significant contributions from Ekman transport (purple). It should be noted that both the turbulent and Ekman components of the flow are highly variable, but the variability has been averaged out in the mean seasonal cycle. Ekman transport through time (not shown) reach magnitudes of $10 \mathrm{~km}^{3} /$ day, with the largest values occurring between September-December. Turbulent fluxes have smaller magnitudes, reaching over $6 \mathrm{~km}^{3}$ /day in fall, and have lower values during winter months (January-April) with a maximum value of almost 3 $\mathrm{km}^{3} /$ day (not shown).

Net freshwater advection (Fig. 14, blue) is directed out of the interior in all experiments. Comparing the HIUC and CTRL experiments (Fig. 14e and f), about three times more freshwater is exported out of the interior from January-April than CTRL, in addition to peak export in October being larger as well (blue). Peak import in July is similar in both experiments. The total freshwater flux is mostly determined by the mean component of the flow, having a comparable seasonal cycle. The mean flow in summer has been shown to have an anticyclonic component in eastern Hudson Bay, generated by the spring freshet and reinforced by the mean wind patterns, causing freshwater to enter the interior, as discussed in Gough et al. (2005) and Ridenour et al. (2019). The net and mean components of the volume flux are directed out of the interior and are similar in magnitude for both experiments. The turbulent component of the flow is also similar for both volume and freshwater transports for the two experiments. Ekman volume transport in both experiments is directed out of the interior, with HIUC having more water directed out of the interior on average than CTRL. Ekman freshwater transport is a source to the interior in CTRL, while it is a sink in the HIUC experiment. This can be explained by more freshwater entering the interior with the DT runoff at the beginning of the year compared to the HIUC discharge, along with weaker freshwater export in the second half of the year (Fig. 14).

The HCAL experiment (Fig. 14c and g) is different from the other two $1 / 4^{\circ}$ experiments as the annual mean $-0.18 \mathrm{~Sv}$ streamline is not present in southeastern Hudson Bay. This results in weaker exchange between the boundary and the interior compared to both HIUC and CTRL, and is most similar to the HIRES interior-boundary exchange. The turbulent component of the flow in HCAL is a net source of both volume and freshwater to the interior while Ekman transport is a net sink of freshwater and volume. Ekman transport is still a source of freshwater in summer and a sink in fall, however magnitudes of the annual cycle are reduced. Similarly for both the mean and total freshwater transports, magnitudes are weaker in both summer and fall in HCAL compared to HIUC and CTRL. 


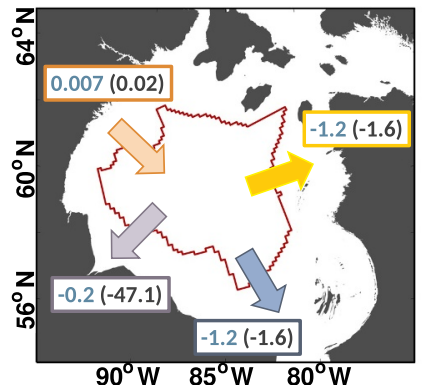

(a)

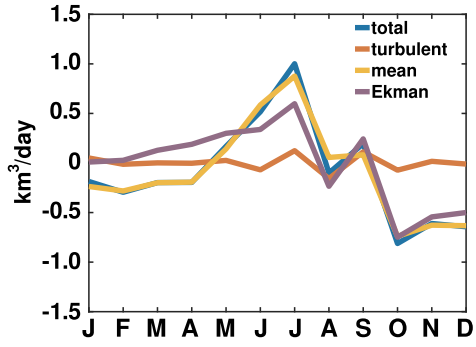

(e)

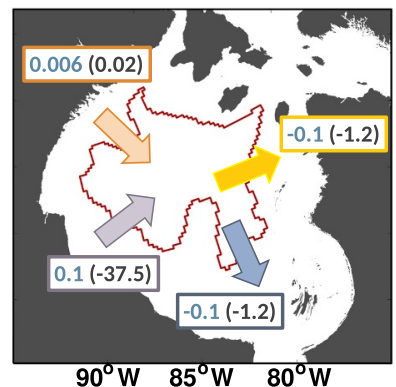

(b)

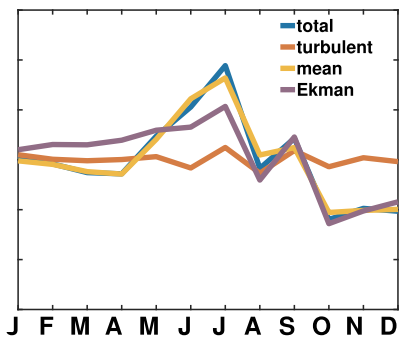

(f)

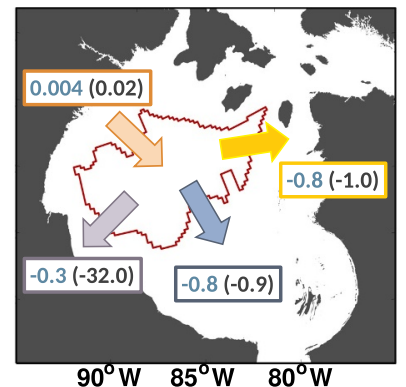

(c)

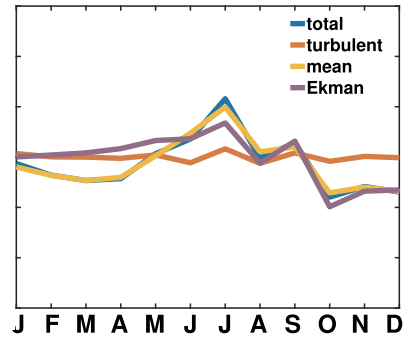

(g)

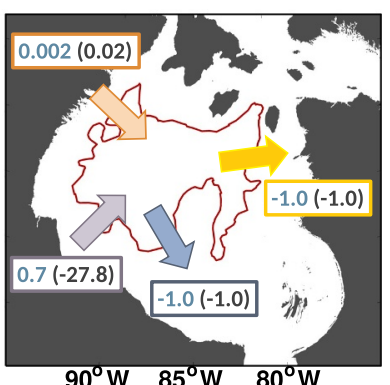

(d)

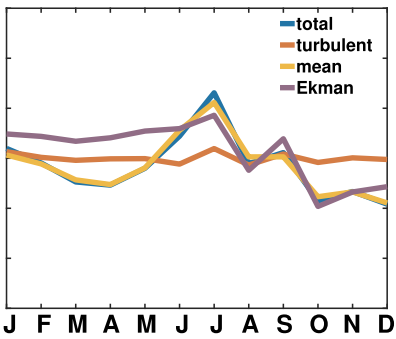

(h)

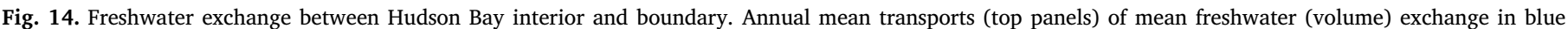

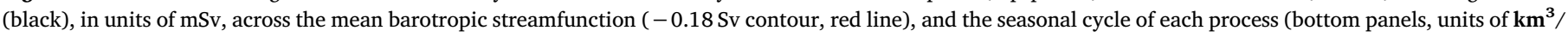

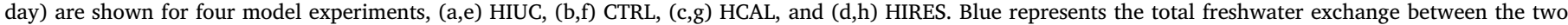

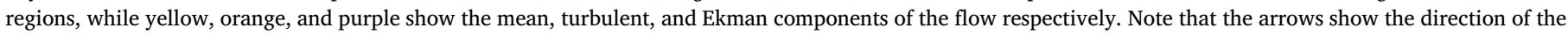

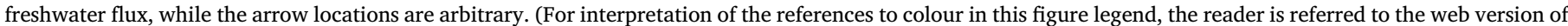
this article.)

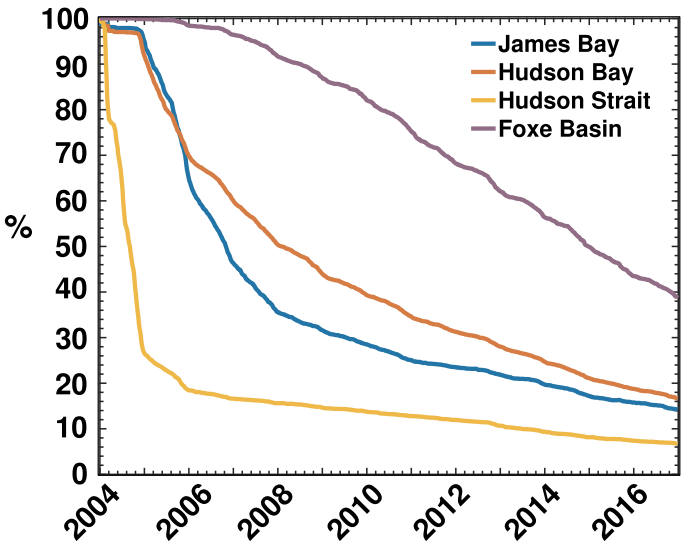

(a)

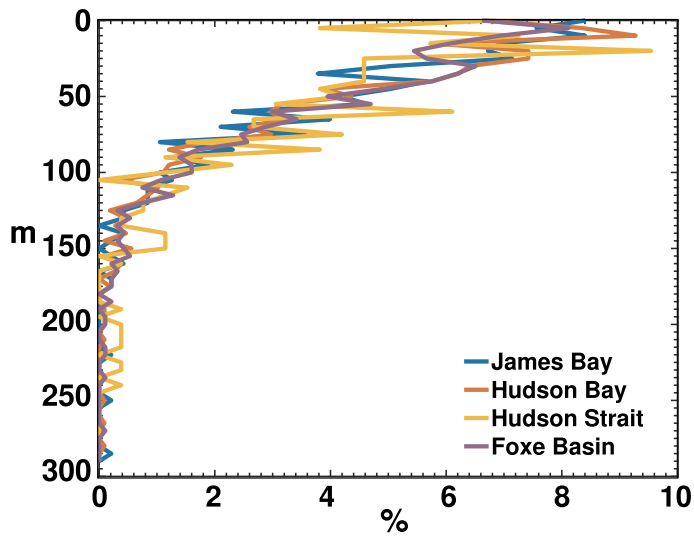

(b)

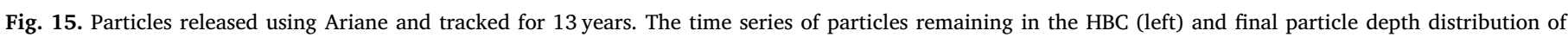
remaining particles in the HBC (right) for each of the four regions.

Fig. 14d and h show freshwater exchange between the interior and boundary regions of Hudson Bay for the HIRES run. The annual mean barotropic streamfunction has a more convoluted shape in the $1 / 12$ o than the $1 / 4$ o experiments. The freshwater exchange between the interior and boundary is still dominated by the mean component of the flow (yellow), but with a diminished seasonal cycle. We see larger magnitudes of freshwater export out of the interior in late winter/early spring, which leads to larger net export values on average in HIRES than CTRL, for both the mean and total freshwater exchange components. Ekman volume transport is directed out of the interior on average, however, Ekman freshwater transport is directed into the interior on average in the HIRES experiment (Fig. 14d), as with CTRL, but with a larger magnitude. Ekman transport of freshwater into the interior is maintained for the first seven months of the year, while in CTRL, import of freshwater over the first three months is less than HIRES (Fig. 14f and h). The turbulent component of the flow is small in both experiments, but more significant on shorter time scales. This, however, is beyond the scope of this study.

Freshwater flowing from the interior to the boundary, instead of from the boundary to the interior, may seem counter intuitive, since runoff flows directly into the boundary. In this analysis, we do not include the lateral movement of sea ice in our freshwater exchanges between the two regions. Therefore, sea ice imported to the interior is solid freshwater, and is only included in the lateral fluxes if the sea ice melts and the resulting liquid freshwater is transported across the streamline. Another source of freshwater export from the interior is if water more saline than the reference value leaves the boundary and crosses the streamline, which results in a freshwater flux out of the interior to the boundary.

There are still open questions with regards to the retention of 
freshwater in the bay. Is the bay opposite to the Beaufort Gyre, with a predominantly cyclonic flow with freshwater retention events? This topic requires further study, as this might provide some key insights to processes occurring in the bay and the resulting freshwater fluxes to the North Atlantic.

\section{4. $H B C$ residence time}

This section presents the residence time of riverine water within the HBC based on the results of Ariane particle tracking. Note that the analysis is based on the CTRL simulation only. Fig. 15 shows the percentage of Ariane particles remaining in the HBC (Fig. 15a), and the particle depth distribution at the end of December 2016 for each of the four regions (Fig. 12f). By the end of the $13^{\text {th }}$ year after being released in Hudson Bay, $16.6 \%$ of particles remain in the HBC. The majority of particles are in the top $60 \mathrm{~m}$, while a few particles reach depths of $200 \mathrm{~m}$ and below. Particles that remain are fairly well distributed around Hudson and James Bays, as well as along the southern coast of Hudson Strait. Hudson Bay particles do enter Foxe Basin, and for the most part, remain in the south, near Southampton Island, with few being located farther north.

The majority of particles released in James Bay leave the HBC after 4 years, with a slow decline to $14.2 \%$ in the following 9 years (Fig. 15a). As with Hudson Bay, the highest concentration of particles are within the top $60 \mathrm{~m}$. Remaining James Bay particles are found to be well distributed in Hudson Bay and in the Hudson Strait outflow. Once again, particles that reach Foxe Basin, are mostly in the south, at varying depths, ranging from the surface to almost $300 \mathrm{~m}$.

The region with the most particles remaining in the HBC is Foxe Basin, at 38.7\% (Fig. 15a). Foxe Basin particles are well distributed throughout the HBC, and have a smoother depth profile than the other HBC regions. Foxe Basin particles are mixed to deeper depths north of Southampton Island, likely due to the many polynyas in the region (Prinsenberg, 1986a). Particles are more concentrated in eastern Foxe Basin and likely were released in the vicinity, where they have remained.

Fitting a trend line to the time series of the number of particles remaining in the $\mathrm{HBC}$, we can estimate the residence time for particles released in each region. Using a 10\% threshold, we found that particles released in Hudson Bay, using an exponential curve, can remain in the HBC for 17.6 years, while Foxe Basin has a residence time of 32.2 years, also using an exponential trend line. Hudson Strait has the shortest residence time of 9.5 years (no trend line used). Finally, James Bay was estimated to have a residence time of 21.5 years using an exponential curve. We suggest a topic of future work would be to investigate the temporal and spatial variability of residence times. Particles released during the spring freshet may have shorter residence times than those released in winter, while particles released in northwestern Hudson Bay likely have a longer residence time than those released along the eastern coast.

\section{Discussion}

In this study we investigated the sensitivity of freshwater in the HBC to model resolution and runoff forcing. The results obtained here also have implications for pathways and residence times of various nutrients or pollutants commonly found in river discharge.

In terms of the freshwater budget, our estimates of surface fluxes are comparable to Prinsenberg (1988), with our peak freshwater fluxes in the summer of $18 \mathrm{~km}^{3} /$ day compared to their $12 \mathrm{~km}^{3} /$ day (including areas of both Hudson Bay and James Bay). Minimum surface fluxes are similar in both studies. Hudson and James Bay surface fluxes calculated by St-Laurent et al. (2011) are roughly 8-23\% lower than in this study. Mean Hudson and James Bay runoff shown here accounts for 37\%-41\% $\left(510-756 \mathrm{~km}^{3} / \mathrm{yr}\right)$ of the freshwater budget, while average runoff in StLaurent et al. (2011) accounts for $41 \%$ of the freshwater budget for the same region. Additionally, total freshwater advection out of the Hudson and James Bay area was $50 \%$ of the freshwater budget $\left(743 \mathrm{~km}^{3} / \mathrm{yr}\right.$; StLaurent et al., 2011), while our estimates are lower, ranging from $32 \%-38 \%$.

Earlier estimates of freshwater and volume fluxes through Fury and Hecla Strait vary, with winter volume (freshwater) fluxes of 40 (1.2) $\mathrm{mSv}$ (Barber, 1965), and summer volume fluxes of 100 (3.0) $\mathrm{mSv}$ (Sadler, 1982). Using the aforementioned volume fluxes, Straneo and Saucier (2008b) estimated the year round volume and freshwater fluxes to be 70 and $2.8 \mathrm{mSv}\left(S_{\text {ref }}=33\right)$ respectively. Our results are closest to the winter season fluxes from Barber (1965). Our larger freshwater flux estimates are partly due to the fact that Fury and Hecla Strait is wider in the model domain than in reality due to the model resolution, while previous assumptions, such as constant salinity and volume transport for consecutive months of the year, might also lead to discrepancies between studies.

Hudson Strait net volume and freshwater fluxes were estimated to be 100-101 and 29-35 mSv respectively (Straneo and Saucier, 2008b; Saucier et al., 2004; Drinkwater, 1988). The net freshwater and volume fluxes simulated here are smaller, ranging from 25.5 to 31.2 and 75.3-84.4 mSv respectively. Additionally, Straneo and Saucier (2008a) estimate the volume outflow of Hudson Strait to be between 1 and $1.2 \mathrm{~Sv}$, whereas in this suite of experiments, we have a volume outflow range of $1.2-1.4 \mathrm{~Sv}$.

Fluxes through Roes Welcome Sound and the three eastern gates connecting Hudson Bay and Hudson Strait were modelled by St-Laurent et al. (2011), who found freshwater and volume fluxes through Roes Welcome Sound to be 0.5 and $18 \mathrm{mSv}$ respectively, both of which are lower than the fluxes simulated here. We find that our range for freshwater fluxes through the passage between Southampton Island and Quebec of $15.5-23.8 \mathrm{mSv}$, are lower than or comparable to the StLaurent et al. (2011) value of $24 \mathrm{mSv}$, with the HIRES experiment having the best agreement. Volume fluxes obtained here are in the range of $44.3-65.5 \mathrm{mSv}$, compared to the volume flux of $35 \mathrm{mSv}$ found by St-Laurent et al. (2011).

The volume fluxes through the Southampton-Baffin Island gate in this study range from 1.6 to $24.9 \mathrm{mSv}$ out of Foxe Basin. These values are lower than the modelling study done by Defossez et al. (2012), who found a net volume flux of $56 \mathrm{mSv}$ out of Foxe Basin. The discrepancy between studies can be explained by the horizontal and vertical resolutions, as well as different averaging time periods.

The freshwater exchange between the Hudson Bay boundary and interior has been studied previously by St-Laurent et al. (2011, 2012). In agreement with their studies, our results also show that freshwater from the boundary is transported to the interior in summer via Ekman transport, and vice versa in the fall. They neglected the eddy and mean components of the flow and assumed the flow could be separated into the geostrophic and Ekman components. Our 5-day mean Ekman fluxes agree in magnitude with those modelled by St-Laurent et al. (2011). Our turbulent component of the flow, however, has fluxes into the interior up to $6 \mathrm{~km}^{3} /$ day, and thus cannot be ignored on shorter time scales. However, investigating the specifics of the turbulent component is beyond the scope of this study.

Regarding residence time of river discharge, our results indicate that the residence time for the HBC could be as long as 32.2 years. This is longer than the previous estimates, 6.6 years by Prinsenberg (1984, 1986b) and 3-7 years (depending on the fitting method to reach the $10 \%$ threshold) by St-Laurent et al. (2011). However, considering river discharge can mix into the deep waters (Granskog et al., 2011), our estimated residence time in Hudson Bay (17.6 years) and James Bay (21.5 years) compares well with the Hudson Bay deep water residence time (4-14 years) based on the apparent oxygen utilisation measurements (Pett et al., 1982). Even though a full investigation of river runoff pathways is beyond the scope of this paper, it brings up interesting questions as to the processes involved, such as those mentioned by Granskog et al. (2011), and runoff pathways from different regions in 
the HBC.

Our study has provided a look at present day freshwater dynamics in the HBC, in addition to evaluating the sensitivity of the region to model resolution and runoff forcing. Using different estimates of runoff allows us to test the sensitivity of the region, which has importance for future studies. Our main findings in this paper are:

- Sensitivity to runoff Overall, the seasonality of freshwater is robust, however the strength and magnitude of fluxes were impacted. Increased discharge in runoff datasets lead to stronger circulation patterns, while decreased discharge and seasonality throughout the year lead to weaker circulation. Lower freshwater and volume exchange between subregions and between the HBC and North Atlantic were also due to decreased discharge and seasonality.

- Sensitivity to model resolution Increased model resolution was able to reproduce freshwater contained in sea ice, however there was generally little impact on fluxes through gates with simple flow dynamics. Small scale processes were found to be important through Southampton-Baffin Island gate. Freshwater interior-boundary exchange was also impacted by higher model resolution via the Ekman and mean components of the flow.

- HBC residence time Particles released along the coast indicate that the residence time for the $\mathrm{HBC}$ is as long as 32.2 years, with $\mathrm{HBC}$ residence times for Foxe Basin, Hudson Bay, James Bay, and Hudson Strait being $32.2,17.6,21.5$, and 9.5 years respectively, agreeing with previous estimates.

Our work highlights topics for future work such as the role of the turbulent component of the flow and freshwater retention in Hudson Bay. A complete understanding of the pathways of river discharge, in addition to regional variability of residence time, is important for tracing various nutrients in addition to pollutants, such as mercury (Hare et al., 2010; Wang and Zhang, 2013), both of which can impact the ecosystem and food sources for communities in the HBC.

\section{Acknowledgements}

We would like to thank Environment and Climate Change Canada for the use of the CGRF forcing fields, as well as the producers of GLORYS for the reanalysis data that we use to initialize our model simulations as well as providing our model with open boundary conditions. Thank you to Dr. Gregory Smith who provided the CGRF atmospheric forcing to force our ocean model. This work is part of the BaySys project, thus we thank the Natural Sciences and Engineering Research Council of Canada and Manitoba Hydro for funding the BaySys project (CRDPJ 470028-14). We are grateful for the use of the HYPE dataset which was provided by BaySys Team 2 (Matt MacDonald, Tricia Stadnyk, and Stephen Déry). We are grateful to Dr. J Bamber for the Greenland melt dataset, and to Aviso, ArcticNet, ICES, and MEDS for their observational data which was used to evaluate the model simulations. Observational datasets such as SST data from NOAA ESRL/ PSD, ice drift from EUMETSAT OSISAF, and ice concentration and thickness data from Integrated Climate Data Centre at the University of Hamburg were also greatly appreciated for model evaluation. Computational resources used for our work were provided by Westgrid and Compute Canada, which made this work possible. We would like to thank two anonymous reviewers who helped improve this manuscript.

\section{References}

Aagaard, K., Carmack, E.C., 1989. The role of sea ice and other fresh water in the Arctic circulation. Journal of Geophysical Research: Oceans 94, 14485-14498. https://doi. org/10.1029/JC094iC10p14485.

Andersson, J.C.M., Pechlivanidis, I.G., Gustafsson, D., Donnelly, C., Arheimer, B., 2013. Key factors for improving large-scale hydrological model performance. In: Lekkas, T. (Ed.), Proceedings of the 13th International Conference on Environmental Science and Technology, Univ Aegean; Global Network Environm Sci \& Technol. Global Nest,
Secritariat, Univ, Aegean, 30, Voulgaroktonou Str, Athens, GR 114 72, Greece. 13th International Conference on Environmental Science and Technology (CEST), Athens, Greece, Sep 05-07, 2013pp. 77-88.

Bamber, J., van den Broeke, M., Ettema, J., Lenaerts, J., Rignot, E., 2012. Recent large increases in freshwater fluxes from Greenland into the North Atlantic. Geophys. Res. Lett. 39. https://doi.org/10.1029/2012GL052552.

Barber, F.G., 1965. Current observations in Fury and Hecla Strait. J. Fish. Res. Board Can. 22, 225-229. https://doi.org/10.1139/f65-021.

Blanke, B., Delecluse, P., 1993. Variability of the tropical Atlantic Ocean simulated by a general circulation model with two different mixed-layer physics. J. Phys. Oceanogr. 23, 1363-1388. https://doi.org/10.1175/1520-0485(1993)023<1363:VOTTAO > 2 . $0 . \mathrm{CO} ; 2$.

Blanke, B., Raynaud, S., 1997. Kinematics of the Pacific equatorial undercurrent: an Eulerian and Lagrangian approach from GCM results. J. Phys. Oceanogr. 27, 1038-1053. https://doi.org/10.1175/1520-0485(1997)027<1038:KOTPEU > 2.0. $\mathrm{CO} ; 2$.

Blanke, B., Arhan, M., Madec, G., Roche, S., 1999. Warm water paths in the equatorial Atlantic as diagnosed with a general circulation model. J. Phys. Oceanogr. 29, 2753-2768. https://doi.org/10.1175/1520-0485(1999)029<2753:WWPITE $>2.0$. CO; 2 .

de Boisséson, E., Thierry, V., Mercier, H., Caniaux, G., Desbruyères, D., 2012. Origin, formation and variability of the Subpolar Mode Water located over the Reykjanes Ridge. Journal of Geophysical Research: Oceans 117. https://doi.org/10.1029/ 2011JC007519.

Bougeault, P., Lacarrere, P., 1989. Parameterization of orography-induced turbulence in a mesobeta-scale model. Mon. Weather Rev. 117, 1872-1890.

Castro de la Guardia, L., Myers, P.G., Derocher, A.E., Lunn, N.J., Terwisscha van Scheltinga, A.D., 2017. Sea ice cycle in western Hudson Bay, Canada, from a polar bear perspective. Mar. Ecol. Prog. Ser. 564, 225-233.

Dai, A., Trenberth, K.E., 2002. Estimates of freshwater discharge from continents: latitudinal and seasonal variations. J. Hydrometeorol. 3, 660-687. https://doi.org/10. 1175/1525-7541(2002)003<0660:EOFDFC > 2.0.CO;2.

Dai, A., Qian, T., Trenberth, K.E., Milliman, J.D., 2009. Changes in continental freshwater discharge from 1948 to 2004. J. Clim. 22, 2773-2792. https://doi.org/10.1175/ 2008JCLI2592.1.

Defossez, M., Saucier, F., Myers, P., Caya, D., Dumais, J., 2012. Comparing winter and summer simulated estuarine circulations in Foxe Basin, Canada. Atmosphere-Ocean 50, 386-401.

Déry, S.J., Stadnyk, T.A., MacDonald, M.K., Koenig, K.A., Guay, C., 2018. Flow alteration impacts on Hudson Bay river discharge. Hydrol. Process. 32, 3576-3587. https://doi. org/10.1002/hyp.13285.

Déry, S.J., Stieglitz, M., McKenna, E.C., 2005. Characteristics and trends of river discharge into Hudson, James, and Ungava Bays, 1964-2000. J. Clim. 18, 2540-2557.

Déry, S.J., Hernández-Henríquez, M.A., Burford, J.E., Wood, E.F., 2009. Observational evidence of an intensifying hydrological cycle in northern Canada. Geophys. Res. Lett. 36. https://doi.org/10.1029/2009GL038852.

Déry, S.J., Mlynowski, T.J., Hernández-Henríquez, M.A., Straneo, F., 2011. Interannual variability and interdecadal trends in Hudson Bay streamflow. J. Mar. Syst. 88, 341-351.

Déry, S.J., Stadnyk, T.A., MacDonald, M.K., Gauli-Sharma, B., 2016. Recent trends and variability in river discharge across northern Canada. Hydrol. Earth Syst. Sci. 20, 4801-4818.

Drinkwater, K.F., 1988. On the mean and tidal currents in Hudson Strait. Atmosphere-Ocean 26, 252-266.

Dukhovskoy, D.S., Myers, P.G., Platov, G., Timmermans, M.L., Curry, B., Proshutinsky, A., Bamber, J.L., Chassignet, E., Hu, X., Lee, C.M., Somavilla, R., 2016. Greenland freshwater pathways in the sub-Arctic seas from model experiments with passive tracers. Journal of Geophysical Research: Oceans 121, 877-907. https://doi.org/10. 1002/2015JC011290.

Fichefet, T., Maqueda, M.A.M., 1997. Sensitivity of a global sea ice model to the treatment of ice thermodynamics and dynamics. Journal of Geophysical Research: Oceans 102, 12609-12646. https://doi.org/10.1029/97JC00480.

Gagnon, A.S., Gough, W.A., 2002. Hydro-climatic trends in the Hudson Bay Region, Canada. Canadian Water Resources Journal/Revue canadienne des ressources hydriques 27, 245-262. https://doi.org/10.4296/cwrj2703245.

Gagnon, A.S., Gough, W.A., 2005. Trends in the dates of ice freeze-up and breakup over Hudson Bay, Canada. Arctic 58, 370-382.

Gaspar, P., Gregoris, Y., Lefevre, J., 1990. A simple eddy kinetic-energy model for simulations of the oceanic vertical mixing - tests at station Papa and long-term upper ocean study site. Journal of Geophysical Research: Oceans 95, 16179-16193.

Gelfan, A., Gustafsson, D., Motovilov, Y., Arheimer, B., Kalugin, A., Krylenko, I., Lavrenov, A., 2017. Climate change impact on the water regime of two great Arctic rivers: modeling and uncertainty issues. Clim. Chang. 141, 499-515. https://doi.org/ 10.1007/s10584-016-1710-5.

Gillard, L.C., Hu, X., Myers, P.G., Bamber, J.L., 2016. Meltwater pathways from marine terminating glaciers of the Greenland ice sheet. Geophys. Res. Lett. 43, 10,873-10,882. https://doi.org/10.1002/2016GL070969.

Gough, W., Cornwell, A., Tsuji, L., 2004a. Trends in seasonal sea ice duration in southwestern Hudson Bay. Arctic 57, 299-305. https://doi.org/10.14430/arctic507.

Gough, W.A., Gagnon, A.S., Lau, H.P., 2004b. Interannual variability of Hudson Bay ice thickness. Polar Geogr. 28, 222-238. https://doi.org/10.1080/789610188.

Gough, W.A., Robinson, C., Hosseinian, R., 2005. The influence of James Bay river discharge on Churchill, Manitoba sea level. Polar Geogr. 29, 213-223. https://doi.org/ 10.1080/789610202.

Granskog, M.A., Macdonald, R.W., Mundy, C.J., Barber, D.G., 2007. Distribution, characteristics and potential impacts of chromophoric dissolved organic matter (CDOM) 
in Hudson Strait and Hudson Bay, Canada. Cont. Shelf Res. 27, 2032-2050.

Granskog, M.A., Kuzyk, Z.Z.A., Azetsu-Scott, K., Macdonald, R.W., 2011. Distributions of runoff, sea-ice melt and brine using $\delta^{18} \mathrm{O}$ and salinity data - a new view on freshwater cycling in Hudson Bay. J. Mar. Syst. 88, 362-374.

Hare, A.A., Stern, G.A., Kuzyk, Z.Z.A., Macdonald, R.W., Johannessen, S.C., Wang, F., 2010. Natural and anthropogenic mercury distribution in marine sediments from Hudson Bay, Canada. Environmental Science \& Technology 44, 5805-5811. https:// doi.org/10.1021/es100724y.

Hochheim, K.P., Barber, D.G., 2010. Atmospheric forcing of sea ice in Hudson Bay during the fall period, 1980-2005. Journal of Geophysical Research: Oceans 115. https:// doi.org/10.1029/2009JC005334.

Hochheim, K.P., Barber, D.G., 2014. An update on the ice climatology of the Hudson Bay system. Arct. Antarct. Alp. Res. 46, 66-83. https://doi.org/10.1657/1938-4246-46. 1.66 .

Holdsworth, A.M., Myers, P.G., 2015. The influence of high-frequency atmospheric forcing on the circulation and deep convection of the Labrador Sea. J. Clim. 28, 4980-4996. https://doi.org/10.1175/JCLI-D-14-00564.1.

Holmes, R.M., McClelland, J.W., Peterson, B.J., Tank, S.E., Bulygina, E., Eglinton, T.I., Gordeev, V.V., Gurtovaya, T.Y., Raymond, P.A., Repeta, D.J., Staples, R., Striegl, R.G., Zhulidov, A.V., Zimov, S.A., 2012. Seasonal and annual fluxes of nutrients and organic matter from large rivers to the Arctic Ocean and surrounding seas. Estuar. Coasts 35, 369-382. https://doi.org/10.1007/s12237-011-9386-6.

Hu, X., Myers, P.G., 2013. A Lagrangian view of Pacific water inflow pathways in the Arctic Ocean during model spin-up. Ocean Model. 71, 66-80. https://doi.org/10. 1016/j.ocemod.2013.06.007.

Hu, X., Sun, J., Chan, T.O., Myers, P.G., 2018. Thermodynamic and dynamic ice thickness contributions in the Canadian Arctic Archipelago in NEMO-LIM2 numerical simulations. Cryosphere 12, 1233-1247. https://doi.org/10.5194/tc-12-1233-2018.

Hunke, E.C., Dukowicz, J.K., 1997. An elastic-viscous-plastic model for sea ice dynamics. J. Phys. Oceanogr. 27, 1849-1867. https://doi.org/10.1175/1520-0485(1997) $027<1849$ :AEVPMF > 2.0.CO;2.

Kowal, S., Gough, W.A., Butler, K., 2017. Temporal evolution of Hudson Bay sea ice (1971-2011). Theor. Appl. Climatol. 127, 753-760. https://doi.org/10.1007/ s00704-015-1666-9.

Landy, J.C., Ehn, J.K., Babb, D.G., Thériault, N., Barber, D.G., 2017. Sea ice thickness in the eastern Canadian Arctic: Hudson Bay Complex \& Baffin Bay. Remote Sens. Environ. 200, 281-294. https://doi.org/10.1016/j.rse.2017.08.019.

Large, W., Yeager, S., 2004. Diurnal to decadal global forcing for ocean and sea-ice models: the data sets and flux climatologies. In: NCAR/TN-460 + STR NCAR Technical Note. National Center for Atmospheric Research.

Lavergne, T., Eastwood, S., Teffah, Z., Schyberg, H., Breivik, L.A., 2015. Sea ice motion from low-resolution satellite sensors: an alternative method and its validation in the Arctic. Journal of Geophysical Research: Oceans 115. https://doi.org/10.1029/ 2009JC005958.

Lazier, J., Hendry, R., Clarke, A., Yashayaev, I., Rhines, P., 2002. Convection and restratification in the Labrador Sea, 1990-2000. Deep-Sea Res. I Oceanogr. Res. Pap. 49, 1819-1835. https://doi.org/10.1016/S0967-0637(02)00064-X.

Lindström, G., Pers, C., Rosberg, J., Strömqvist, J., Arheimer, B., 2010. Development and testing of the HYPE (Hydrological Predictions for the Environment) water quality model for different spatial scales. Hydrol. Res. 41, 295-319. https://doi.org/10. 2166/nh.2010.007.

Lique, C., Treguier, A.M., Blanke, B., Grima, N., 2010. On the origins of water masses exported along both sides of Greenland: a Lagrangian model analysis. Journal of Geophysical Research: Oceans 115. https://doi.org/10.1029/2009JC005316.

Lozier, M.S., Li, F., Bacon, S., Bahr, F., Bower, A.S., Cunningham, S.A., de Jong, M.F., de Steur, L., deYoung, B., Fischer, J., Gary, S.F., Greenan, B.J.W., Holliday, N.P., Houk, A., Houpert, L., Inall, M.E., Johns, W.E., Johnson, H.L., Johnson, C., Karstensen, J., Koman, G., Le Bras, I.A., Lin, X., Mackay, N., Marshall, D.P., Mercier, H., Oltmanns, M., Pickart, R.S., Ramsey, A.L., Rayner, D., Straneo, F., Thierry, V., Torres, D.J., Williams, R.G., Wilson, C., Yang, J., Yashayaev, I., Zhao, J., 2019. A sea change in our view of overturning in the subpolar North Atlantic. Science 363, 516-521. https:// doi.org/10.1126/science.aau6592.

MacDonald, M.K., Stadnyk, T.A., DÃ@ry, S.J., Braun, M., Gustafsson, D., Isberg, K., Arheimer, B., 2018. Impacts of 1.5 and $2.0 \hat{A}^{\circ} \mathrm{C}$ warming on pan-Arctic River discharge into the Hudson Bay complex through 2070. Geophys. Res. Lett. 0. https:// doi.org/10.1029/2018GL079147.

Madec, G., the NEMO team, 2008. NEMO Ocean Engine. Note du Pole de Modélisation.

Madec, G., Delécluse, P., Imbard, M., Lévy, C., 1998. Opa 8.1 ocean general circulation model reference manual. In: Note du Pole de Modélisation. vol. 11 (91 p).

Masina, S., Storto, A., Ferry, N., Valdivieso, M., Haines, K., Balmaseda, M., Zuo, H., Drevillon, M., Parent, L., 2017. An ensemble of eddy-permitting global ocean reanalyses from the MyOcean project. Clim. Dyn. 49, 813-841. https://doi.org/10. 1007/s00382-015-2728-5.

McGovern, P., Gough, W., 2015. East-west asymmetry in coastal temperatures of Hudson Bay as a proxy for sea ice. Arctic 68, 445-452. https://doi.org/10.14430/arctic4522.

Müller, V., Kieke, D., Myers, P.G., Pennelly, C., Mertens, C., 2017. Temperature flux carried by individual eddies across $47 \hat{\mathrm{A}}^{\circ} \mathrm{N}$ in the Atlantic Ocean. Journal of Geophysical Research: Oceans. https://doi.org/10.1002/2016JC012175.

Pett, R., Roff, J., I.P., M., 1982. Some observations and deductions concerning the deep waters of Hudson Bay. Nat. Can. 767-774.

Prinsenberg, S., 1984. Freshwater contents and heat budgets of James Bay and Hudson Bay. Cont. Shelf Res. 3, 191-200. https://doi.org/10.1016/0278-4343(84)90007-4.

Prinsenberg, S., 1986a. Chapter 12 on the physical oceanography of Foxe Basin. In: Martini, I. (Ed.), Canadian Inland Seas. Volume 44 of Elsevier Oceanography Series Elsevier, pp. 217-236. https://doi.org/10.1016/S0422-9894(08)70905-X.

Prinsenberg, S., 1986b. Chapter 9 salinity and temperature distributions of Hudson Bay and James Bay. Elsevier Oceanography Series 44, 163-186. https://doi.org/10.1016/ S0422-9894(08)70902-4.

Prinsenberg, S., 1988. Ice-cover and ice-ridge contributions to the freshwater contents of Hudson Bay and Foxe Basin. Arctic 41, 6-11. https://doi.org/10.14430/arctic1686.

Rawlins, M.A., Steele, M., Holland, M.M., Adam, J.C., Cherry, J.E., Francis, J.A., Groisman, P.Y., Hinzman, L.D., Huntington, T.G., Kane, D.L., Kimball, J.S., Kwok, R., Lammers, R.B., Lee, C.M., Lettenmaier, D.P., McDonald, K.C., Podest, E., Pundsack, J.W., Rudels, B., Serreze, M.C., Shiklomanov, A., Skagseth, Öystein, Troy, T.J., Vörösmarty, C.J., Wensnahan, M., Wood, E.F., Woodgate, R., Yang, D., Zhang, K., Zhang, T., 2010. Analysis of the Arctic system for freshwater cycle intensification observations and expectations. J. Clim. 23, 5715-5737. https://doi.org/10.1175/ 2010JCLI3421.1.

Reynolds, R.W., Smith, T.M., Liu, C., Chelton, D.B., Casey, K.S., Schlax, M.G., 2007. Daily high-resolution-blended analyses for sea surface temperature. J. Clim. 20, 5473-5496. https://doi.org/10.1175/2007JCLI1824.1.

Ridenour, N.A., Hu, X., Sydor, K., Myers, P.G., Barber, D.G., 2019. Revisiting the circulation of Hudson Bay: evidence for a seasonal pattern. Geophys. Res. Lett. 46. https:// doi.org/10.1029/2019GL082344.

Sadler, H.E., 1982. Water flow into Foxe Basin through Fury and Hecla Strait. Nat. Can. 701-707.

Saucier, F., Dionne, J., 1998. A 3-D coupled ice-ocean model applied to Hudson Bay, Canada: the seasonal cycle and time-dependent climate response to atmospheric forcing and runoff. J. Geophys. Res. Oceans 103, 27689-27705.

Saucier, F.J., Senneville, S., Prinsenberg, S., Roy, F., Smith, G., Gachon, P., Caya, D., Laprise, R., 2004. Modelling the sea ice-ocean seasonal cycle in Hudson Bay, Foxe Basin and Hudson Strait, Canada. Clim. Dyn. 23, 303-326.

Shiklomanov, I.A., Shiklomanov, A.I., 2003. Climatic change and the dynamics of river runoff into the Arctic Ocean. Water Resources 30, 593-601. https://doi.org/10. 1023/B:WARE.0000007584.73692.ca.

Smith, G.C., Roy, F., Mann, P., Dupont, F., Brasnett, B., Lemieux, J.F., Laroche, S., Bélair, S., 2014. A new atmospheric dataset for forcing ice-ocean models: evaluation of reforecasts using the Canadian global deterministic prediction system. Q. J. R. Meteorol. Soc. 140, 881-894. https://doi.org/10.1002/qj.2194.

Spreen, G., Kaleschke, L., Heygster, G., 2008. Sea ice remote sensing using AMSR-E 89$\mathrm{GHz}$ channels. Journal of Geophysical Research: Oceans 113. https://doi.org/10. 1029/2005JC003384.c02S03.

St-Laurent, P., Straneo, F., Dumais, J.F., Barber, D.G., 2011. What is the fate of the river waters of Hudson Bay? J. Mar. Syst. 88, 352-361.

St-Laurent, P., Straneo, F., Barber, D.G., 2012. A conceptual model of an Arctic sea. Journal of Geophysical Research: Oceans 117. https://doi.org/10.1029/ 2011JC007652.

Straneo, F., 2006. Heat and freshwater transport through the central Labrador Sea. J. Phys. Oceanogr. 36, 606-628. https://doi.org/10.1175/JPO2875.1.

Straneo, F., Saucier, F., 2008a. The outflow from Hudson Strait and its contribution to the Labrador Current. Deep-Sea Res. I 55, 926-946.

Straneo, F., Saucier, F.J., 2008b. The Arctic-subarctic exchange through Hudson Strait. In: Dickson, R.R., Meincke, J., Rhines, P. (Eds.), Arctic-Subarctic Ocean Fluxes: Defining the Role of the Northern Seas in Climate. Springer Netherlands, Dordrecht, pp. 249-261. https://doi.org/10.1007/978-1-4020-6774-7__.

Wang, F., Zhang, J., 2013. Mercury contamination in aquatic ecosystems under a changing environment: implications for the Three Gorges Reservoir. Chin. Sci. Bull. 58, 141-149. https://doi.org/10.1007/s11434-012-5490-7.

Yang, J., 2006. The seasonal variability of the Arctic Ocean Ekman transport and its role in the mixed layer heat and salt fluxes. J. Clim. 19, 5366-5387. https://doi.org/10. 1175/JCLI3892.1.

Zhang, X., He, J., Zhang, J., Polyakov, I., Gerdes, R., Inoue, J., Wu, P., 2012. Enhanced poleward moisture transport and amplified northern high-latitude wetting trend. Nat. Clim. Chang. 3, 47-51. 